\title{
Osteopathy and resistance to vitamin $D$ toxicity in mice null for vitamin $D$ binding protein
}

\author{
Fayez F. Safadi, ${ }^{1,2}$ Paul Thornton, ${ }^{1,2}$ Holly Magiera, ${ }^{1,2}$ Bruce W. Hollis, ${ }^{3}$ Michael Gentile, ${ }^{4}$ \\ John G. Haddad, ${ }^{1}$ Stephen A. Liebhaber, ${ }^{1,2,5}$ and Nancy E. Cooke ${ }^{1,2}$ \\ ${ }^{1}$ Department of Medicine, and \\ 2Department of Genetics, University of Pennsylvania School of Medicine, Philadelphia, Pennsylvania 19104-6144, USA \\ ${ }^{3}$ Department of Pediatrics, Medical University of South Carolina, Charleston, South Carolina, 29425, USA \\ ${ }^{4}$ Merck Research Laboratories, West Point, Pennsylvania, 19486, USA \\ ${ }^{5}$ Howard Hughes Medical Institute, University of Pennsylvania School of Medicine, Philadelphia, Pennsylvania 19104-6144, USA \\ Address correspondence to: Nancy E. Cooke, 700 Clinical Research Building, 415 Curie Boulevard, Philadelphia, Pennsylvania \\ 19104-6144, USA. Phone: (215) 898-4425; Fax: (215) 898-0189; E-mail: necooke@mail.med.upenn.edu \\ Fayez F. Safadi and Paul Thornton contributed equally to this work. \\ This study is dedicated to the memory of John G. Haddad \\ Received for publication September 16, 1998, and accepted in revised form November 25, 1998.
}

\begin{abstract}
A line of mice deficient in vitamin D binding protein (DBP) was generated by targeted mutagenesis to establish a model for analysis of DBP's biological functions in vitamin D metabolism and action. On vitamin $\mathrm{D}$-replete diets, $\mathrm{DBP}^{-/-}$mice had low levels of total serum vitamin $\mathrm{D}$ metabolites but were otherwise normal. When maintained on vitamin $\mathrm{D}$-deficient diets for a brief period, the $\mathrm{DBP}^{-/-}$, but not $\mathrm{DBP}^{+/+}$, mice developed secondary hyperparathyroidism and the accompanying bone changes associated with vitamin D deficiency. DBP markedly prolonged the serum half-life of $25(\mathrm{OH}) \mathrm{D}$ and less dramatically prolonged the half-life of vitamin D by slowing its hepatic uptake and increasing the efficiency of its conversion to $25(\mathrm{OH}) \mathrm{D}$ in the liver. After an overload of vitamin $\mathrm{D}, \mathrm{DBP}^{-/-}$mice were unexpectedly less susceptible to hypercalcemia and its toxic effects. Peak steady-state mRNA levels of the vitamin $\mathrm{D}$-dependent calbindin- $\mathrm{D}_{9 \mathrm{~K}}$ gene were induced by $1,25(\mathrm{OH})_{2} \mathrm{D}$ more rapidly in the $\mathrm{DBP}^{-/-}$mice. Thus, the role of DBP is to maintain stable serum stores of vitamin D metabolites and modulate the rates of its bioavailability, activation, and end-organ responsiveness. These properties may have evolved to stabilize and maintain serum levels of vitamin $\mathrm{D}$ in environments with variable vitamin $\mathrm{D}$ availability.
\end{abstract}

J. Clin. Invest. 103:239-251 (1999).

\section{Introduction}

Vitamin $\mathrm{D}$ binding protein (DBP), also known as the group-specific component of serum ( $\mathrm{G}_{\mathrm{c}}$-globulin), is a member of the albumin, $\alpha$-fetoprotein, and $\alpha$-albumin multigene family $(1,2)$. DBP is a highly polymorphic serum protein predominantly synthesized in the liver as a single-chain glycoprotein of $\sim 58 \mathrm{kDa}$ (3). The serum concentration of human DBP is $4-8 \mu \mathrm{M}$ and its serum halflife is $2.5-3$ days. DBP has a high-affinity binding site for $25(\mathrm{OH}) \mathrm{D}\left(5 \times 10^{8} \mathrm{M}^{-1}\right)$, the major circulating form of vitamin $\mathrm{D}$ that is generated by 25 -hydroxylation of vitamin $\mathrm{D}$ in the liver. This site also binds $1,25(\mathrm{OH})_{2} \mathrm{D}$, the active form of the vitamin, as well as the parental vitamin $\mathrm{D}$ itself, both with somewhat lower affinity $\left(4 \times 10^{7} \mathrm{M}^{-1}\right)(4)$. Vitamin D sterols are necessary to maintain normal serum calcium homeostasis and bony development. Deficiency of vitamin D results in the bone diseases of osteomalacia and rickets, diseases characterized by formation of poorly calcified and structurally impaired bones. DBP has several biological activities in addition to its ability to bind vitamin D. DBP binds avidly to G-actin $\left(2 \times 10^{9} \mathrm{M}^{-1}\right)$ via a binding domain in its carboxy terminus $(5,6)$; this binding can sequester circulating monomeric G-actin, preventing polymerization into F-actin after cellular trauma (7). DBP can activate macrophages in vitro (8) and enhances C5a-mediated chemotaxis (9). A definitive approach to testing the multiple function(s) of DBP in vivo, and most particularly its role in vitamin $\mathrm{D}$ metabolism and action, has not been available.

The role of DBP in vitamin D action is not defined. However, it is likely that it functions in accordance with the "free-hormone" hypothesis. This hypothesis suggests that plasma sterols are trapped in the vascular compartment via their association with a corresponding set of serum binding proteins. These complexes provide an available reservoir of sterol hormones; the sterols can be made available to cells by their dissociation from the binding protein (10). Additional roles of the binding proteins might include facilitation of sterol/steroid entry into the cell, as suggested by the identification of cell surface receptors for certain serum steroid binding proteins $(11,12)$; facilitation of its intracellular bioactivity and gene activation; or protection from excess free hormone (13).

The highly polymorphic structure of DBP has led to its use as a serum protein marker for population-genetics studies. Sera from many thousands of individuals from all five continents have been studied for variations in the electrophoretic mobility of DBP (14). Despite this intensive analysis, no individuals have been identified who are null for DBP. This observation has led to the suggestion that one or more functions of DBP may be essential to human viability (4). In this report, a mouse line lacking DBP was successfully established by targeted disruption of the endogenous murine DBP gene. 
These mice have been used to test essential role(s) of DBP and specifically to delineate the role(s) played by $\mathrm{DBP}$ in vitamin $\mathrm{D}$ metabolism and action.

\section{Methods}

\section{Materials}

All restriction and modification enzymes were purchased from New England Biolabs (Beverly, Massachusetts, USA). Chemicals and tissue culture supplies were purchased from Sigma Chemical Co. (St. Louis, Missouri, USA) unless otherwise stated. cDNA probe labeling kits were purchased from Boehringer-Mannheim Biochemicals (Indianapolis, Indiana, USA). Oligonucleotides were synthesized by the Nucleic Acid Core Facility of the Children's Hospital of Philadelphia (Philadelphia, Pennsylvania, USA). $\left[{ }^{3} \mathrm{H}\right]$ vitamin $\mathrm{D}_{3}(15 \mathrm{Ci} / \mathrm{mmol})$ and $25(\mathrm{OH})[26,(27)$-methyl$\left.{ }^{3} \mathrm{H}\right]$ vitamin $\mathrm{D}_{3}\left[25(\mathrm{OH})\left[{ }^{3} \mathrm{H}\right] \mathrm{D}_{3} ; 15 \mathrm{Ci} / \mathrm{mmol}\right]$ were purchased from Amersham Life Sciences Inc. (Arlington Heights, Illinois, USA). The $\left[{ }^{3} \mathrm{H}\right]$ vitamin $\mathrm{D}_{3}$ used at the beginning of the study went out of production during the course of these experiments, and studies were completed using $\left[{ }^{3} \mathrm{H}\right]$ vitamin $\mathrm{D}_{3}(3.85 \mathrm{Ci} / \mathrm{mmol})$ provided by Michael Holick (Boston University, Boston, Massachusetts, USA). $1,25(\mathrm{OH})_{2}$ vitamin $\mathrm{D}_{3}\left[1,25(\mathrm{OH})_{2} \mathrm{D}_{3}\right]$ was provided by Milan Uskokovic (Hoffman-La Roche, Nutley, New Jersey, USA). Hybridization probes in these studies were as follows: an 865-bp rat DBP EcoRI cDNA fragment (2), a 180-bp mouse calbindin-D $9 \mathrm{k}$ EcoRI cDNA fragment (clone B6; gift from Elizabeth Bruns, University of Virginia, Charlottesville, Virginia, USA), and a 400-bp mouse-rpL32 EcoRI-HindIII fragment (15).

Generation of $\mathrm{DBP}^{-1-}$ mice. The mouse (m) DBP gene was cloned from a 129 SV mouse genomic library (Lambda FXII vector; Stratagene, La Jolla, California, USA), using the 875-bp 5' end of the rat $(\mathrm{r}) \mathrm{DBP} \mathrm{cDNA}$ as hybridization probe. Four clones were obtained. Exon content and organization were determined by restriction mapping and hybridization to exon fragments of the homologous rDBP gene (16). An 8.8-kb EcoRI fragment of the $24-\mathrm{kb}$ "clone 2" containing exons $2-8$ was selected for generation of the targeting vector. A $1.8-\mathrm{kb}$ SalI-XhoI fragment containing the PGK-promoter/neomycin phosphotransferase $\left(\right.$ PGK-neo $\left.{ }^{r}\right)$ cassette was blunt-end ligated into exon 5 of the mDBP fragment at the BamHI site to generate pDBPN5. To shorten the construct, pDBPN5 was digested with SalI and KpnI by removing a $2.3-\mathrm{kb}$ fragment containing exons 2 and 3 generating pDBPN5(4-8). The diphtheria toxin A chain gene (DTA) cassette (17) (generous gift from Barbara Knowles, The Jackson Laboratory, Bar Harbor, Maine, USA) on a 2.7-kb SalI-KpnI fragment was ligated to the KpnI-SalI pDBPN5(4-8) fragment, and circularized recombinants were selected. This procedure resulted in the targeting vector, pDBPN5(4-8)-DTA.

The targeting vector was transfected into passage $9 \mathrm{R} 1$ embryonic stem (ES) cells (a gift from Andras Nagy, Mount Sinai Hospital, Samuel Lunenfield Research Institute, Toronto, Ontario, Canada). The ES cells were grown on mitomycin C-treated SLN2 feeder cells plated on gelatin-coated plates (18). The ES cells were maintained in the dedifferentiated state by growth in LIFD cell (Genetics Institute, Cambridge, Massachusetts) conditioned media. R1 cells ( $0.8 \mathrm{ml}$; passage 13$)$ at a concentration of $7 \times$ $10^{6} / \mathrm{ml}$ were electroporated with $40 \mu \mathrm{g}$ of linearized pDBPN5DTA using a Gene Pulser (Bio-Rad Laboratories, Hercules, California, USA) at $240 \mathrm{~V} / 500 \mu \mathrm{F}$ and replated onto feeder cells. G418 (GIBCO BRL, Gaithersburg, Maryland) at $200 \mu \mathrm{g} / \mathrm{ml}$ was added $48 \mathrm{~h}$ later. After 8 days of culture, resistant colonies were picked and transferred to 96-well plates. After splitting into triplicate 96-well plates, DNA was isolated from lysed cells, digested with EcoRI, resolved on $0.8 \%$ agarose gels, and Southern blotted with a probe generated from $\mathrm{mDBP}$ exon 2 .

One hundred ninety-five surviving ES clones were analyzed, and three had been successfully targeted. Clone D1 was expanded, and 10-15 cells were microinjected into 3.5 -day-old blastocytes from a C57B1/6J mouse by the University of Pennsylvania Transgenic and Chimeric Mouse Core. Five chimeric mice resulted, and four transmitted the targeted $\mathrm{mDBP}$ gene to their agouti offspring after backcross to C57BL/6J mates. The mouse colony was maintained within a microbiological barrier facility, and animals were anesthetized with tribromoethanol (Avertin) at $300 \mathrm{mg} / \mathrm{g}$ body weight during all invasive procedures and before sacrifice.

\section{Genotyping}

PCR assay. Tail DNA $(1 \mu \mathrm{g})$ was subjected to PCR with two sets of oligonucleotide primers. The first set included primers from exon 5, DBP-A (5'-CGCCTCTGCCACTTTTAGTTG-3') and DBP-B (5'-GCATACAGTTGGGTTTGCAG-3'). This primer set spanned the neor ${ }^{r}$ cloning site and generated a 100-bp fragment only from the $\mathrm{DBP}^{+/+}$allele. A second, confirming primer set included DBP-C, also from exon 5 (5'-CCTCTGCCACTTTTAGTTGCTTAC-3'), and DBP-D, derived from neo ${ }^{r}$ gene sequences (5'-GGATGTGGAATGTGTGCGAG- $\left.3^{\prime}\right)$. These primers generated a $180-\mathrm{kb}$ fragment specific to the $\mathrm{DBP}^{-/-}$ allele. For both sets of oligonucleotides, PCR was carried out for 30 cycles: $94^{\circ} \mathrm{C}$ for $1 \mathrm{~min}, 54^{\circ} \mathrm{C}$ for $30 \mathrm{~s}$, and $72^{\circ} \mathrm{C}$ for $2 \mathrm{~min}$.

Radial immunodiffusion assay. One percent agarose containing 3\% polyclonal anti-rDBP antibody (cross-reactive with mDBP) was poured onto a glass backing, and circular wells were cut into the solidified matrix. Test mouse sera or controls $(2 \mu \mathrm{l})$ were loaded into each well and allowed to diffuse for $48 \mathrm{~h}$. The gels were rinsed for $24 \mathrm{~h}$, first with PBS, and then with distilled water. Gels were stained with $0.2 \%$ Coomassie brilliant blue in $5 \%$ methanol and $5 \%$ trichloroacetic acid for $30 \mathrm{~min}$, and then destained with 5\% methanol and $7.5 \%$ acetic acid for $24 \mathrm{~h}$ and air dried. The diameters of the stained immunoprecipitated circles were proportionate to the amount of $\mathrm{mDBP}$ in each serum sample.

Western analysis. Mouse sera were resolved on 7.5\% SDS-polyacrylamide gels. Gels were electrotransferred onto nitrocellulose membranes, incubated with rabbit anti-rDBP, and visualized by enhanced chemiluminescence (ECL kit; Amersham Life Sciences Inc.) as described previously (19).

$25(\mathrm{OH}) \mathrm{D}$ binding assay. Mouse sera were analyzed for $25(\mathrm{OH}) \mathrm{D}$ binding by incubation with $25(\mathrm{OH})\left[{ }^{3} \mathrm{H}\right] \mathrm{D}_{3}$ in the presence of increasing concentrations of cold $25(\mathrm{OH}) \mathrm{D}_{3}$ as described previously (20). Scatchard analysis was carried out to estimate the mean binding capacity (21). Results shown were representative of three separate analyses, each carried out in duplicate.

RNA isolation and Northern analysis. RNA was extracted from primary tissues using TRIzol Ultrapure (Life Technologies Inc., Gaithersburg, Maryland, USA) according to the manufacturer's protocol. To obtain high-quality RNA from the intestine, the RNA extraction procedure was modified (22). RNA $(10 \mu \mathrm{g})$ was denatured in $20 \%$ MOPS solution $(0.04 \mathrm{M}$ MOPS; $0.01 \mathrm{M}$ sodium acetate; $2 \mathrm{mM}$ EDTA, $\mathrm{pH} 7.0$; $50 \%$ formamide; and $6.25 \%$ formaldehyde) at $65^{\circ} \mathrm{C}$ for $10 \mathrm{~min}$. The RNA was separated in $1 \%$ agarose-formaldehyde gels, transferred overnight to ZetaBind membranes (CUNO Inc., Meriden, Connecticut, USA), and hybridized with ${ }^{32} \mathrm{P}$-labeled probes at $42^{\circ} \mathrm{C}$ for $16 \mathrm{~h}$. After washing the filters, the radioactivity in each band was quantified by PhosphorImager (Molecular Dynamics, Sunnyvale, California, USA).

Blood chemistries. Mice were maintained for the noted time periods on either sterile standard laboratory diet or vitamin D-deficient diet (Purina test diet No. 5826C-5: no vitamin D, calcium 0.60\%, phosphorus 0.40\%; North Penn Feeds Inc., Lansdale, Pennsylvania, USA). Animals were sacrificed and blood was collected by cardiac puncture. Plasma calcium, phosphorous, and alkaline phosphatase were measured using a Kodak Ektachem Analyzer. Parathyroid hormone (PTH) measurements by immune assay were kindly provided by the labo- 
ratory of Leonard Deftos, University of California at San Diego, San Diego, California, USA (23). 1,25(OH $)_{2} \mathrm{D}$ and $25(\mathrm{OH}) \mathrm{D}$ were measured by RIA $(24,25)$.

Bone histomorphometric analyses. Age- (6-8 months) and sexmatched $\mathrm{DBP}^{+/+}$and $\mathrm{DBP}^{-/-}$mice were maintained on standard laboratory chow (controls) or the vitamin $\mathrm{D}$-deficient diet for 8 weeks in temperature-controlled rooms with 12-h light and 12 -h dark cycles. Animals were fluorochrome double-labeled with calcein in neutral PBS $(0.5 \mathrm{mg} /$ animal $)$ delivered intraperitoneally 10 days and 3 days before sacrifice. Femurs were removed and dehydrated in $70 \%$ ethanol for at least 3 days. Bone samples were embedded in methylmethacrylate, and 5$\mu \mathrm{m}$ sections were stained with Masson's trichrome (26) as described previously (27). They were examined using a semiautomated image analysis system (BIOQUANT IV; R\&M Biometrics, Nashville, Tennessee, USA) by an investigator blinded to group allocations. Unstained sections $(8-10 \mu \mathrm{m})$ were examined for fluorochrome-based indices. Histomorphometric analyses were performed using the Statview statistical package (Abacus Concepts Inc., Berkeley, California, USA) and presented in the format of Parfitt et al. (28).

Preparation of vitamin D sterols for intravenous injection. $\left[{ }^{3} \mathrm{H}\right]$ vita$\min \mathrm{D}_{3}$ and $25(\mathrm{OH})\left[{ }^{3} \mathrm{H}\right] \mathrm{D}_{3}$ were dried under a stream of nitrogen and stored in the dark at $4{ }^{\circ} \mathrm{C}$. These $\left[{ }^{3} \mathrm{H}\right]$ sterols were preincubated, at $4^{\circ} \mathrm{C}$ overnight $\left(\left[{ }^{3} \mathrm{H}\right]\right.$ vitamin $\left.\mathrm{D}_{3}\right)$ or for $1 \mathrm{~h}$ $\left(25(\mathrm{OH})\left[{ }^{3} \mathrm{H}\right] \mathrm{D}_{3}\right)$, with aliquots of sera collected from either $\mathrm{DBP}^{+/+}$or $\mathrm{DBP}^{-/-}$mice. In this way, the sterols could be solubilized in either DBP-free or normal serum without using organic solvents. Approximately equal cpm were delivered using equal aliquots, indicating equivalent recovery. Such preincubated $\mathrm{DBP}^{+/+}$sera were used for injections into $\mathrm{DBP}^{+/+}$mice, and preincubated $\mathrm{DBP}^{-/-}$sera were used for injections into $\mathrm{DBP}^{-/-}$mice. $1,25(\mathrm{OH})_{2} \mathrm{D}_{3}$, stored dry under argon and shielded from light, was solubilized in ethanol, dried under nitrogen, and similarly incubated with homologous sera from $\mathrm{DBP}^{+/+}$or $\mathrm{DBP}^{-/-}$mice at $4^{\circ} \mathrm{C}$ overnight, and was injected for the calbindin- $\mathrm{D}_{9 \mathrm{~K}}$ gene induction experiments.

Vitamin D kinetics. Age-matched groups of $\mathrm{DBP}^{+/+}$and $\mathrm{DBP}^{-/-}$ mice were fed vitamin $\mathrm{D}_{3}$-deficient diets for 4-6 weeks. Animals were fasted overnight before the injections. Each animal was weighed at the beginning of the experiment. $\left[{ }^{3} \mathrm{H}\right]$ vitamin $\mathrm{D}_{3}$ or $25(\mathrm{OH})\left[{ }^{3} \mathrm{H}\right] \mathrm{D}_{3}(0.5 \mu \mathrm{Ci}$, or $100,000 \mathrm{cpm})$ in homologous sera was injected intravenously into the tail vein. Animals were sacrificed at different time points over $24 \mathrm{~h}$. Blood, and in some cases liver, and/or kidneys were collected. Heparinized blood was spun at 2,500 rpm to collect the plasma, and aliquots were counted in BCS scintillant (Amersham Life Sciences Inc.). An aliquot of each collected tissue was weighed and incubated with NSCII tissue solubilizer (Amersham Life Sciences Inc.) at $1 \mathrm{ml} / 100 \mathrm{mg}$ tissue overnight at $50^{\circ} \mathrm{C}$. After complete solubilization, the samples were cooled and neutralized with glacial acetic acid to decrease chemiluminescence. Final tissue counts were obtained using Ready-Organic scintillation fluid (Beckman Coulter Inc., Fullerton, California, USA) in a refrigerated scintillation counter after chemiluminescence had decayed to a plateau.

For analysis of urinary excretion, $100,000 \mathrm{cpm}$ of $25(\mathrm{OH})\left[{ }^{3} \mathrm{H}\right] \mathrm{D}_{3}$ preincubated with homologous sera was injected intravenously into anesthetized $\mathrm{DBP}^{+/+}$and $\mathrm{DBP}^{-/-}$mice.

a
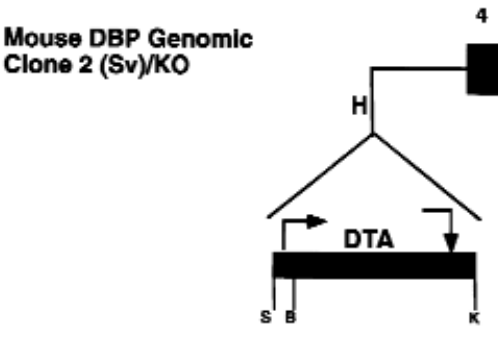

NEGATIVE SELECTION

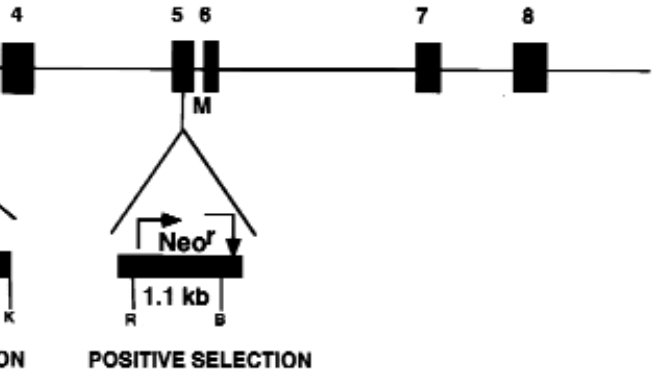

$b$

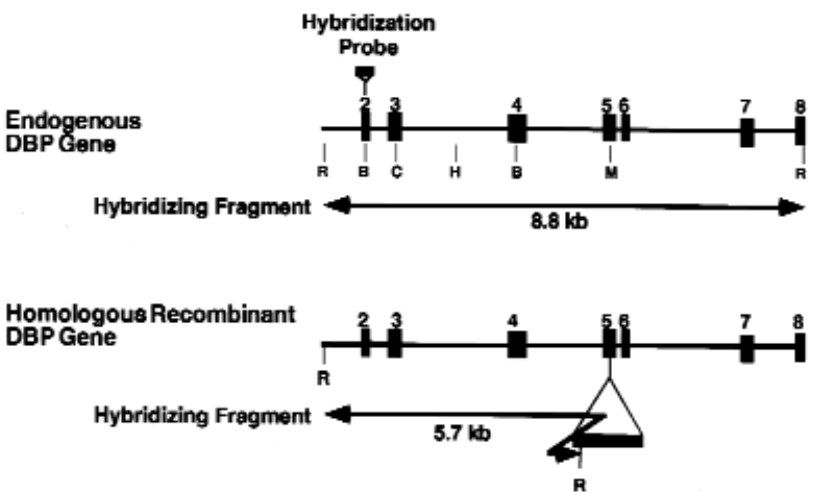

c

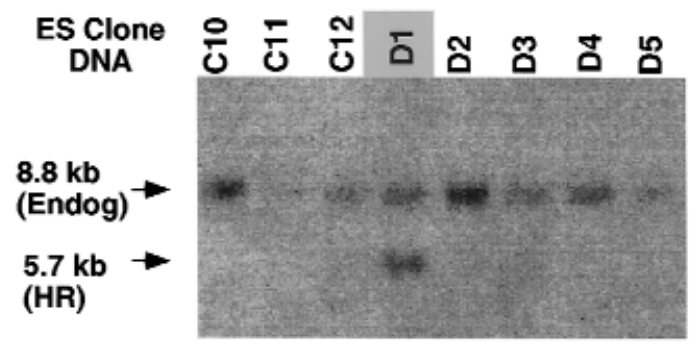

Figure 1

Targeted disruption of the mouse DBP locus. (a) A fragment of mouse genomic DNA containing exons 4-8 of the DBP gene was used to design the targeting vector. A PGK-promoter/neomycin phosphotransferase cassette was inserted at the BamHI ( $\mathrm{M}$ ) site in exon 5 to disrupt the mDBP gene and provide for positive selection. A DTA cassette was ligated to the 5' Hindlll site for selection against random integration. ( $\boldsymbol{b}$ ) Restriction enzyme mapping distinguished the intact from the disrupted DBP allele. A mouse DBP exon 2 probe, located outside of the targeting vector itself, hybridized to an 8.8-kb EcoRI (R) fragment from the native DBP allele and a 5.7-kb EcoRI fragment from the disrupted mDBP allele. Restriction sites are: S, Sall; H, HindIII; B, Bg/II; R, EcoRI; C, Clal; M, BamHI. (c) The targeting vector (a) was transfected into ES cells, G418 selection was applied, and surviving clones were analyzed by Southern blotting. Analysis of 8 representative ES cell lines among the 65 examined is shown. All eight clones contained the native 8.8-kb mouse DBP EcoRI fragment, and one clone (D1) also contained the 5.7-kb fragment, indicative of successful homologous recombination. $D B P$, vitamin D binding protein; DTA, diphtheria toxin A; ES, embryonic stem. 


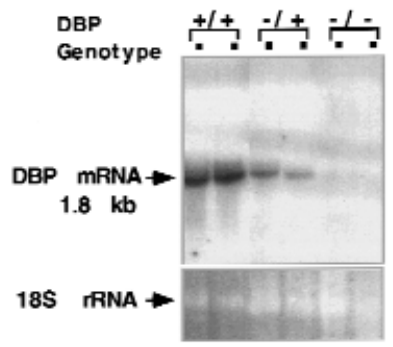

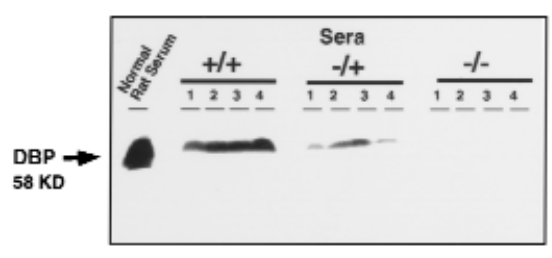

$\boldsymbol{C}$

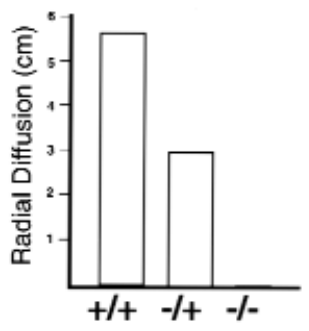

\section{Figure 2}

Functional inactivation of the mouse DBP locus by homologous recombination. (a) An autoradiogram of the Northern blot analysis of total RNA from livers of $\mathrm{DBP}^{+/+}, \mathrm{DBP}^{+/-}$, and $\mathrm{DBP}^{-/-}$mice hybridized with rat DBP cDNA is shown. The full-length $1.8-\mathrm{kb} \mathrm{mDBP}$ mRNA was detected in wild-type mice, present at diminished levels in heterozygous mice, and totally absent in mice homozygous for DBP gene activation. Balanced RNA loading was confirmed by the ethidium bromide staining of 18S rRNA (bottom). (b) Western analysis for serum DBP in 12 mice representing each of the three genotypes is shown. The antibody was a cross-reacting, polyclonal rabbit antiserum to rat DBP. The presence and relative levels of the 58-kDa DBP paralleled the mRNA levels in panel a. (c) Semiquantitative radial immunodiffusion analysis of sera from mice of all three genotypes using the polyclonal antiserum confirmed the absence of DBP in $\mathrm{DBP}^{-/-}$mice. (d) Serum saturation binding analysis using tracer $25(\mathrm{OH})\left[{ }^{3} \mathrm{H}\right] \mathrm{D}_{3}$ in the presence of increasing concentrations of cold $25(\mathrm{OH}) \mathrm{D}_{3}$ is shown. The data were further analyzed by Scatchard plotting (inset). $25(\mathrm{OH})\left[{ }^{3} \mathrm{H}\right] \mathrm{D}_{3}, 25(\mathrm{OH})\left[26,(27)\right.$-methyl- $\left.{ }^{3} \mathrm{H}\right]$ vitamin $\mathrm{D}_{3}$.

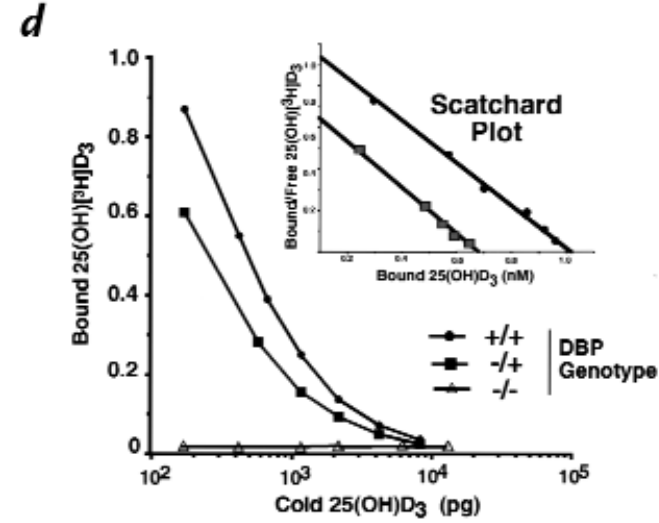

Urine volume was maximized with an injection of $6 \mathrm{ml}$ of PBS intraperitoneally. Urine was collected using metabolic cages 6 and $24 \mathrm{~h}$ later. Aliquots of urine $(100 \mu \mathrm{l})$ from each animal were counted in duplicate, and $500 \mu \mathrm{l}$ was analyzed for $25(\mathrm{OH}) \mathrm{D}$ by RIA. Data were normalized for total urine volumes.

Thin-layer chromatography. Aliquots of the plasma samples from different time points of the $\left[{ }^{3} \mathrm{H}\right]$ vitamin $\mathrm{D}_{3}$ or $25(\mathrm{OH})\left[{ }^{3} \mathrm{H}\right] \mathrm{D}_{3}$ kinetic curves were dissolved in $0.9 \mathrm{ml} \mathrm{PBS}$, extracted with $3 \mathrm{ml}$ of ice-cold methanol/methylene chloride (2:1), then reextracted with $2 \mathrm{ml}$ methylene chloride. The organic extracts were pooled, and methylene chloride was removed by incubation under a stream of nitrogen at $35^{\circ} \mathrm{C}$. Samples were dissolved in $N$-hexane/acetone (92:8) and subjected to TLC on silica G chromatography media (Gelman Sciences Inc., Ann Arbor, Michigan, USA) for fractionation of vitamin D metabolite, as described previously (29). Each silica $G$ plate was dried and then cut into 15 segments $(1 \times 3 \mathrm{~cm})$, which were counted in Ready-Organic scintillation fluid. Purified vitamin $\mathrm{D}_{3}, 25(\mathrm{OH}) \mathrm{D}_{3}$, and $1,25(\mathrm{OH})_{2} \mathrm{D}_{3}$ were used as migration standards, and their positions were localized by visualization under ultraviolet light. The counts from pooled fractions were divided by the total applied counts to yield a percentage of total cpm chromatographed, and these results were plotted.

Kinetics of calbindin- $D_{9 K}$ gene induction. Age-matched $\mathrm{DBP}^{+/+}$and $\mathrm{DBP}^{-/-}$mice were fed vitamin $\mathrm{D}$-deficient diets for 4 weeks to induce a mild vitamin D-deficient state. Animals were then injected intravenously with homologous serum preincubated with $1,25(\mathrm{OH})_{2} \mathrm{D}_{3}(50 \mathrm{ng} /$ animal). Animals were sacrificed at intervals over a 24 -h period. The most proximal $1 \mathrm{~cm}$ of small intestine was isolated and snap-frozen in liquid nitrogen for RNA analyses. Northern blots were carried out as described above and hybridized sequentially with the $\left[{ }^{32} \mathrm{P}\right]$ calbindin- $\mathrm{D}_{9 \mathrm{k}}$ probe, and then with $\left[{ }^{32} \mathrm{P}\right] \mathrm{rpL} 32$ to control for RNA loading. Filters were stripped between hybridizations by incubation in hybridization solution containing $50 \%$ formamide at $65^{\circ} \mathrm{C}$ for $1 \mathrm{~h}$ and exposed overnight to document complete probe removal. Hybridization signals were quantified by PhosphorImager analysis.

Vitamin D toxicity. Groups of $\mathrm{DBP}^{+/+}$and $\mathrm{DBP}^{-/-}$animals maintained on standard diets were injected intravenously with a sublethal dose of vitamin $\mathrm{D}_{3}$ determined in a preliminary study
(1,000 IU/g body weight) dissolved in 1,2-propanediol. Control animals were injected with an equivalent volume of vehicle alone. Animals were weighed daily for 7 days, and the weight losses observed documented vitamin D toxicity. On day 7, animals were sacrificed and serum calcium levels were determined. Kidneys were harvested, fixed, and processed for von Kossa staining.

Data analyses. Scintillation counts from the kinetic experiments were corrected to total body plasma volume or total body mass of each tissue type, respectively. The total plasma volume was estimated from body weight $(0.0275 \mathrm{ml}$ plasma/g) (30). One kidney or a weighed aliquot of liver was solubilized. The total liver mass was estimated to be $4.5 \%$ of total body weight (31). Data were expressed as a percentage of total cpm injected. Data presented were the mean of three to five repeats \pm SEM. The twotailed, paired $t$ test was performed (Statview statistics package), and data were considered significant when $P<0.05$.

\section{Results}

Generation of $\mathrm{DBP}^{-/-}$mice. A fragment of the $\mathrm{mDBP}$ gene spanning exons 2-8 was isolated from a mouse $129 \mathrm{SV}$ genomic library by cross-hybridization with a rat DBP cDNA probe (Fig. 1a). The 8.8-kb genomic insert was restriction-mapped and partially sequenced to confirm its identity and establish restriction sites for vector construction. A vector for homologous recombination was generated by cloning the PGK-neor cassette into the BamHI site into DBP exon 5 and ligating a DTA cassette into intron 3 at the $5^{\prime}$ terminus of the targeting insert (Fig. 1a). Mouse ES cells were electroporated with the targeting insert, and surviving cells (i.e., those lacking the DTA cassette) were selected for resistance to G418. One hundred ninety-five surviving ES colonies were analyzed by Southern blotting (Fig. 1, $b$ and $c$ ). A hybridization probe from exon 2 detected an 8.8-kb EcoRI fragment from the intact mouse DBP gene and a 5.7-kb EcoRI fragment from the disrupted locus. Of three ES cell clones with the disrupt- 

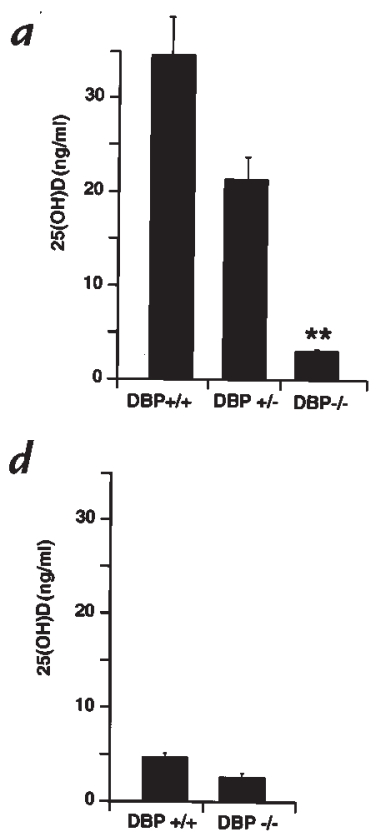

$\boldsymbol{b}$

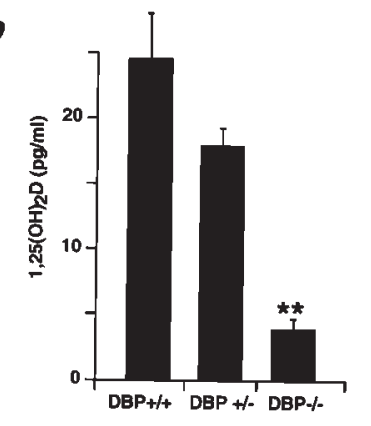

e

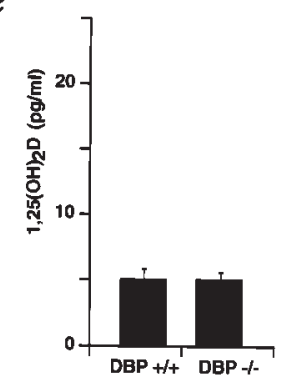

c

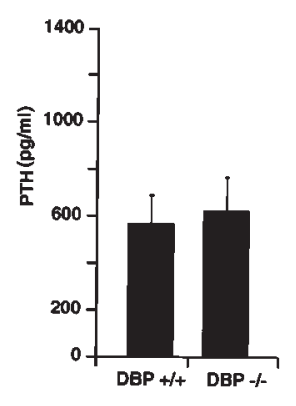

f

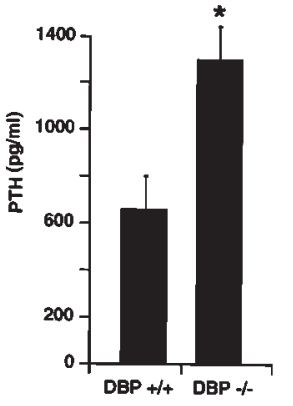

Figure 3

Low serum $25(\mathrm{OH}) \mathrm{D}$ and $1,25(\mathrm{OH})_{2} \mathrm{D}$ levels and secondary hyperparathyroidism after mild dietary vitamin $\mathrm{D}$ deficiency in $\mathrm{DBP}^{-/-}$mice. Groups of $\mathrm{DBP}^{+/+}, \mathrm{DBP}^{+/}$, and $\mathrm{DBP}^{-/-}$mice were fed either standard (vitamin $\left.\mathrm{D}^{+}\right)(\boldsymbol{a}-\boldsymbol{c})$ or vitamin D-deficient (vitamin $\left.\mathrm{D}^{-}\right)(\boldsymbol{d}-\boldsymbol{f})$ diets for 4 weeks. Serum 25(OH)D ( $a$ and $d$ ), $1,25(\mathrm{OH})_{2} \mathrm{D}(b$ and $e)$, and PTH ( $c$ and $f$ ) levels were determined. Data displayed are the mean + SEM from 10 animals. The differences between $\mathrm{DBP}^{+/+}$and $\mathrm{DBP}^{-/-}$groups were statistically significant in $a, b\left({ }^{*} P<0.001\right)$, and $f\left({ }^{*} P<0.01\right) . P T H$, parathyroid hormone. ed DBP allele, a single colony, D1, was selected for subsequent use (Fig. 1c). D1 ES cells were expanded and microinjected into 3.5-day-old blastocytes from a C57Bl $/ 6 \mathrm{~J}$ mouse; five chimeric animals that ranged from $5 \%$ to almost $100 \%$ agouti coat color were obtained. The near-100\% agouti chimeric animals produced only agouti offspring, $56 \%$ of which carried the $\mathrm{DBP}^{-}$allele. $\mathrm{DBP}^{-/+}$ animals were intercrossed; of the initial 177 offspring, 25\% were wild type $\left(\mathrm{DBP}^{+/+}\right), 49 \%$ were heterozygous $\left(\mathrm{DBP}^{+/-}\right)$, and $26 \%$ were homozygous $\left(\mathrm{DBP}^{-/-}\right.$) for the disrupted locus. This distribution, consistent with normal Mendelian inheritance, suggested that $\mathrm{DBP}^{-/-}$mice were of normal viability. Intercrosses of $\mathrm{DBP}^{-/-}$progeny resulted in normal frequency and sizes of litters, indicating normal fertility and fecundity of the $\mathrm{DBP}^{-/-}$males and females. $\mathrm{DBP}^{-/-}$mice appeared grossly normal, had growth curves identical to wild-type littermates, and showed no abnormalities after necropsy and histologic examination of all major organs (data not shown).

Verification of DBP-null state.Loss of expression from the disrupted DBP allele was confirmed by analysis of mRNA and protein. Northern blots of total liver RNA from $\mathrm{DBP}^{+/+}, \mathrm{DBP}^{+/-}$, and $\mathrm{DBP}^{-/-}$mice were generated. The expected 1.8-kb DBP mRNA was detected in the $\mathrm{DBP}^{+/+}$liver, present, but at reduced levels, in $\mathrm{DBP}^{+/-}$ liver, and totally absent from $\mathrm{DBP}^{-/-}$liver (Fig. 2a). Western blots of sera from animals of each genotype confirmed the reduction of DBP in $\mathrm{DBP}^{+/-}$mice and the total absence in $\mathrm{DBP}^{-/-}$mice (Fig. $2 b$ ). Analysis of DBP content in sera by radial immunodiffusion readily distinguished between the levels in the wild-type and carrier mice and confirmed the absence of immunoreactive DBP in DBP ${ }^{-/-}$mouse serum (Fig. $2 c$ ). The simple radial immunodiffusion assay was subsequently used for genotyping. The profiles of total serum proteins as determined by sodium dodecyl sulfate-polyacrylamide gel electrophoresis (SDS-PAGE) were otherwise identical in $\mathrm{DBP}^{-/-}$and $\mathrm{DBP}^{+/+}$sera (not shown). Serum saturation binding analysis using tracer $25(\mathrm{OH})\left[{ }^{3} \mathrm{H}\right] \mathrm{D}_{3}$ was performed to detect any bioactive fragments of DBP that might be produced by the mutant locus. No binding activity was detectable in the $\mathrm{DBP}^{-/}$serum. The affinity constants were essentially identical in wild-type and heterozygous sera $\left(K_{\mathrm{a}}=1.0 \times 10^{-9} \mathrm{M}\right.$ and $\left.0.9 \times 10^{-9} \mathrm{M}\right)$ and comparable to that previously reported for hDBP $(5 \times$ $\left.10^{-8} \mathrm{M}\right)$. From the Scatchard plot, the maximum binding capacity of the $\mathrm{DBP}^{+/+}$serum was estimated as 570 $\mu \mathrm{g} / 1$ and for $\mathrm{DBP}^{+/-}$serum, $380 \mu \mathrm{g} / 1$ (67\% of wild-type) (Fig. 2d). When sera were preincubated with $25(\mathrm{OH})\left[{ }^{3} \mathrm{H}\right] \mathrm{D}_{3}$ and subjected to a native gel electrophoresis (32), the DBP band was absent from $\mathrm{DBP}^{-/-}$ sera and detected at reduced levels in $\mathrm{DBP}^{+/-}$sera compared with that of $\mathrm{DBP}^{+/+}$animals (data not shown). These data demonstrated a complete absence of expression of immunologically or biologically detectable DBP in the $\mathrm{DBP}^{-/-}$mice. The data also suggested that heterozygotes have a minor upregulation of protein expression from the intact DBP allele.

$\mathrm{DBP} \mathrm{P}^{-/}$mice are vitamin $D$-depleted. The consequences of the DBP-null mutation on vitamin D levels and calcium homeostasis were determined. Serum levels of calcium, phosphorous, alkaline phosphatase, $\mathrm{PTH}, 25(\mathrm{OH}) \mathrm{D}$, and $1,25(\mathrm{OH})_{2} \mathrm{D}$ were initially measured in $\mathrm{DBP}^{-/-}$and $\mathrm{DBP}^{+/+}$ littermates maintained on standard laboratory chow containing vitamin $\mathrm{D}$. On this standard diet, $\mathrm{DBP}^{-/-}$mice had significantly lower total serum levels of $25(\mathrm{OH}) \mathrm{D}$ and $1,25(\mathrm{OH})_{2} \mathrm{D}$ than $\mathrm{DBP}^{+/+}$mice (Fig. 3, $a$ and $b$ ). Heterozygotes fell within the intermediate range in both assays. No significant differences in serum calcium, phosphorous, or alkaline phosphatase were observed between wild-type and $\mathrm{DBP}^{-/-}$littermates on a vitamin D-replete diet (Table 1), and the levels of PTH were equivalent for these two groups (Fig. $3 c$ ). Therefore, the low total serum sterol levels in the $\mathrm{DBP}^{-/-}$mice coexisted in equilibrium with adequate intracellular concentrations of $1,25(\mathrm{OH})_{2} \mathrm{D}$ under steady-state conditions, based on 
analysis of the PTH response.

The mice were next stressed by placing them on a vitamin D-deficient diet for four to six weeks. The effects of this diet on calcium and vitamin $\mathrm{D}$ homeostasis were compared between the $\mathrm{DBP}^{-/-}$and wild-type littermates. After four weeks without exogenous vitamin $\mathrm{D}$, the $25(\mathrm{OH}) \mathrm{D}$ and $1,25(\mathrm{OH})_{2} \mathrm{D}$ levels decreased in the wildtype mice to levels comparable to those of the $\mathrm{DBP}^{-/-}$animals, the lowest detection limits of these assays (Fig. 3, $d$ and $e$ ). At this point, both groups became hypophosphatemic and alkaline phosphatase levels increased slightly (Table 1). Serum calcium was maintained at the same level in the $\mathrm{DBP}^{+/+}$and $\mathrm{DBP}^{-/-}$groups. Although no differences between the two groups were noted in serum PTH levels while on standard diet (Fig. 3c), there was a doubling in the mean PTH levels in the $\mathrm{DBP}^{-/-}$group on the vitamin $\mathrm{D}-$ deficient $\operatorname{diet}(P<0.05$; Fig. $3 f)$. Thus, the $\mathrm{DBP}^{-/-}$mice were more sensitive to dietary vitamin $\mathrm{D}$ deficiency than their normal littermates, selectively manifesting secondary hyperparathyroidism.

Bone histomorphometric analyses demonstrated an increased sensitivity of the bone in $\mathrm{DBP} \mathrm{P}^{--}$mice to vitamin $\mathrm{D}$ deficiency. Skeletal radiographs showed no discernible differences between $\mathrm{DBP}^{-/-}$and $\mathrm{DBP}^{+/+}$mice (data not shown). Qualitative bone histological examination and quantitative histomorphometric analyses were carried out to detect

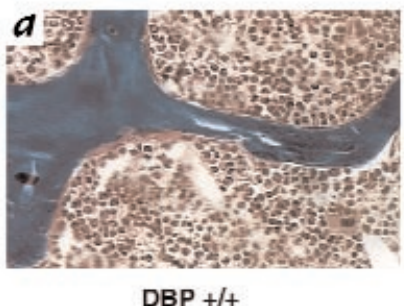

$\mathrm{DBP}+1+$

C
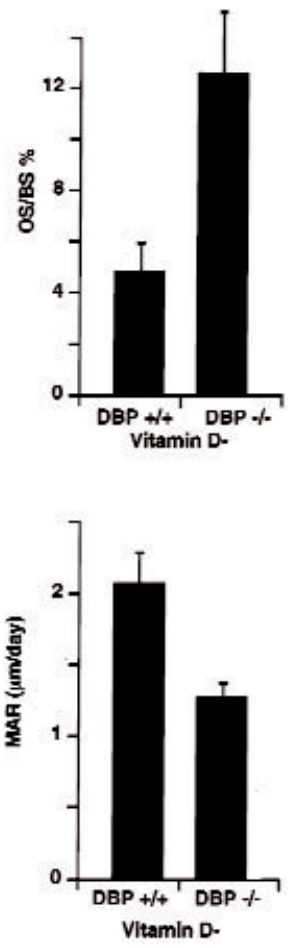

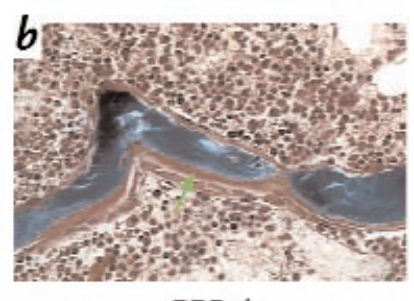

DBP $-1-$

$d$

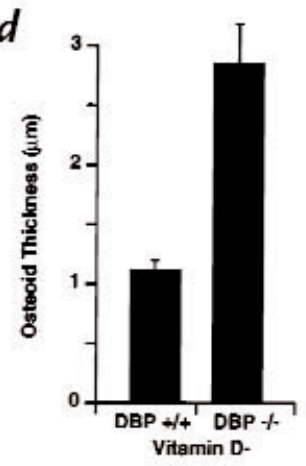

$f$

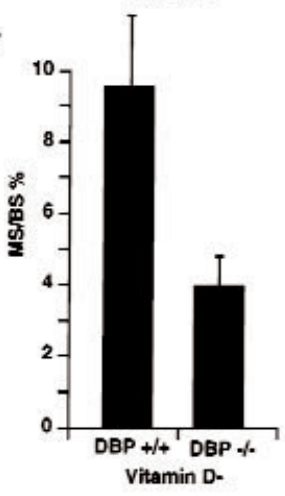

bony abnormalities at a higher level of resolution. The bones of age- and sex-matched $\mathrm{DBP}^{-/-}$and $\mathrm{DBP}^{+/+}$littermates were studied on standard diets and after eight points were analyzed: femoral lengths, trabecular bone volume/tissue volume (BV/TV) in two planes, osteoid surface/bone surface (OS/BS), osteoclast surface/bone surface (OcS/BS), osteoclast number/bone surface (OCN/BS), mineralizing surface/bone surface (MS/BS), mineral apposition rate (MAR), and osteoid thickness (OTh). On standard diets, there were no significant differences between the $\mathrm{DBP}^{+/+}$and $\mathrm{DBP}^{-/}$groups in any of these end points (data not shown), nor was there any distinguishable difference in osteoclast numbers.

On the vitamin $\mathrm{D}$-deficient diet, $\mathrm{BV} / \mathrm{TV}$ was significantly lower in both the $\mathrm{DBP}^{+/+}$and $\mathrm{DBP}^{-/-}$groups compared with values on the standard diet ( $8 \%$ vs. $4 \%, P<$ 0.01 for $\mathrm{DBP}^{+/+}$groups; $12 \%$ vs. $4 \%, P<0.05$ for $\mathrm{DBP}^{-/-}$ groups). This shared decrease confirmed the effectiveness of the vitamin $\mathrm{D}$-deficient diet in altering bone metabolism without regard to the DBP status.

The remaining end points demonstrated a markedly increased and selective sensitivity of the $\mathrm{DBP}^{-/-}$mice to bone changes caused by vitamin D deficiency. OS/BS of the $\mathrm{DBP}^{-/}$group was significantly higher on the vitamin D-deficient diet (from 3.3\% to $8.8 \%, P<0.001$, male animals only; data not shown), whereas the OS/BS in the $\mathrm{DBP}^{+/+}$group was not influenced by diet. A comparison between the two groups after vitamin $\mathrm{D}$ deprivation showed the net result of this differential effect (Fig. $4 c ; P$ $<0.05)$. The accentuated thickening of the osteoid seams in the $\mathrm{DBP}^{-/-}$mice, reflecting osteoblast activity and mineralization, could be appreciated qualitatively in a visual comparison of the Masson's trichrome-stained sections (Fig. 4, $a$ and $b$; arrowhead). This selective effect in the $\mathrm{DBP}^{-/-}$mice was confirmed quantitatively by measurement of the mean OTh (Fig. $4 d ; P<0.001$ ). A significant and selective difference between the $\mathrm{DBP}^{-/-}$ and $\mathrm{DBP}^{+/+}$mice was also noted in the lower MAR and $\mathrm{MS} / \mathrm{BS}$ in the $\mathrm{DBP}^{-/-}$mice (Fig. $4, e$ and $f ; P<0.05$ and $P$ $<0.01$, respectively). When fed a vitamin $\mathrm{D}$-replete diet, weeks on vitamin D-deficient diets. The following end

\section{Figure 4}

Bone mineralization defect after mild dietary vitamin $\mathrm{D}$ deficiency in $\mathrm{DBP}-1-$ mice. Sections of femurs from age- and sex-matched groups of vitamin D-deficient (vitamin $\mathrm{D}^{-}$) $\mathrm{DBP}^{+/+}$and $\mathrm{DBP}^{-/-}$mice were stained with Masson's trichrome. Representative photomicrographs from a $\mathrm{DBP}^{+/+}(\boldsymbol{a})$ and a $\mathrm{DBP}^{-/-}$ (b) mouse are shown. Osteoid seams were characteristically thicker in the $\mathrm{DBP}^{-/-}$group (arrowhead). This difference was not observed in mice fed vitamin D-sufficient chow. $(c-f)$ Quantitative histomorphometric analyses of mice on vitamin D-deficient diets demonstrated significant abnormalities in OS/BS (male animals, $n=5$; trend similar among females, but not significant; $c$ ) and osteoid thickness (both sexes compared, $n=10 ; d$ ) in DBP-/ mice. The bones of mice from both groups were labeled by two injections of the fluorochrome (calcein) at a 7-day interval, and bone sections were subjected to quantitative histomorphometric analyses to determine the amount of mineralization during this period. The MAR (both sexes compared, $n=7$, $8 ; e$ ) and the MS/BS (both sexes compared, $n=6 ; f$ ) were indicative of a quantitative mineralization defect in $\mathrm{DBP}^{-/-}$mice. $\mathrm{DBP}^{+/+}$and $\mathrm{DBP}^{-/-}$mice maintained on normal diets showed no significant differences in any of these parameters (not shown). MAR, mineral apposition rate; MS/BS, mineralizing surface/bone surface; OS/BS, osteoid surface/bone surface. 


\section{Figure 5}

Accelerated clearance of $25(\mathrm{OH})\left[{ }^{3} \mathrm{H}\right] \mathrm{D}_{3}$ from the plasma of DBP-/- mice. (a) $25(\mathrm{OH})\left[{ }^{3} \mathrm{H}\right] \mathrm{D}_{3}$ was preincubated with aliquots of serum from either $\mathrm{DBP}^{+/+}$or $\mathrm{DBP}^{-/-}$mice, and these were injected intravenously into mice of homologous genotype. Plasma was sampled at the indicated times after injection, and tritium counts were obtained. Data were normalized to the calculated total plasma volume and expressed as a percentage of total cpm injected. Data for the time interval from 0 to $24 \mathrm{~h}$ represent the mean \pm SEM of five replicate experiments, and data in the inset depict the mean \pm SEM of four experiments examining the $0-40-\mathrm{min}$ time interval. (b) $25(\mathrm{OH})\left[{ }^{3} \mathrm{H}\right] \mathrm{D}_{3}$ was preincubated with aliquots of $\mathrm{DBP}^{+/+}$or $\mathrm{DBP}^{-/-}$serum and injected intravenously into mice of the same respective genotype. Urine was collected for $24 \mathrm{~h}$ using metabolic cages and was counted. Data are the mean \pm SEM of six determinations $(P<0.01)$. (c) Aliquots of plasma from one of the 0-40-min studies in a were extracted in organic solvent and analyzed by TLC. Data were expressed as a percentage of total cpm chromatographed. The percentage of cpm migrating in the $25(\mathrm{OH}) \mathrm{D}$ region (left) and the polar region (right) of the chromatograph for each time point were plotted.
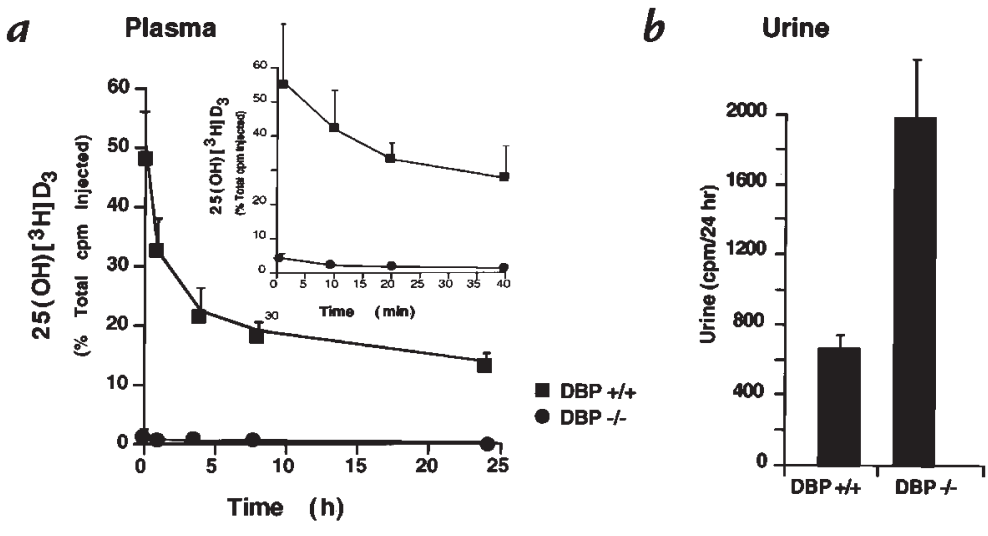

c

TLC Fractionation of Plasma
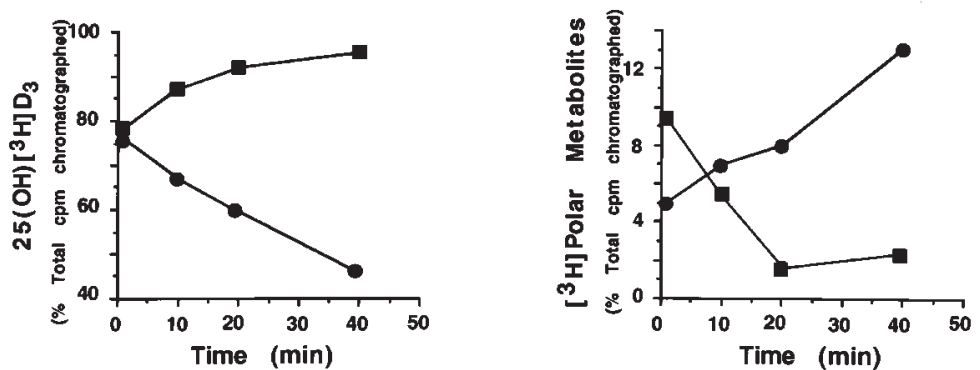

neither $\mathrm{DBP}^{+/+}$nor $\mathrm{DBP}^{-/-}$mice had skeletal abnormalities. However, when fed a vitamin $\mathrm{D}$-deficient diet, the $\mathrm{DBP}^{-/-}$group demonstrated abnormally high osteoblastic activity, with undermineralization of the newly synthesized matrix compared with the matched $\mathrm{DBP}^{+/+}$ group. Thus, the $\mathrm{DBP}^{-/-}$mice demonstrated an increased sensitivity to dietary vitamin $\mathrm{D}$ deprivation by developing hypovitaminosis D osteopathy.

$D B P$ increases the serum half-life of vitamin $D$ and $25(\mathrm{OH}) D$. DBP is the main carrier of vitamin D in the serum and as such has been proposed to play a role in plasma clearance of $25(\mathrm{OH}) \mathrm{D}(33)$. To directly establish the role of DBP in the clearance and distribution of $25(\mathrm{OH}) \mathrm{D}, \mathrm{DBP}^{+/+}$and $\mathrm{DBP}^{-/-}$mice were subjected to four weeks of vitamin $\mathrm{D}$ deprivation sufficient to generate serum 25(OH)D deficiency in both groups (Fig. 3, $d$ and $e$ ). This period was followed by intravenous injection of tracer amounts of $25(\mathrm{OH})\left[{ }^{3} \mathrm{H}\right] \mathrm{D}_{3}$ previously incubated with homologous serum (see Methods). Animals were sacrificed over short (40 minutes) and long (24 hours) time courses, and plasma was collected and counted. In $\mathrm{DBP}^{+/+}$mice, $25(\mathrm{OH})\left[{ }^{3} \mathrm{H}\right] \mathrm{D}_{3}$ was gradually cleared from plasma with $\sim 15 \%$ of the injected isotope still present after 24 hours (Fig. $5 a$ ). In contrast, the half-life of $25(\mathrm{OH})\left[{ }^{3} \mathrm{H}\right] \mathrm{D}_{3}$ in the plasma of the $\mathrm{DBP}^{-/-}$mice was markedly shortened, with a very low level detected in the circulation several minutes after injection (Fig. $5 a$ and inset).

The fate of the rapidly cleared $25(\mathrm{OH})\left[{ }^{3} \mathrm{H}\right] \mathrm{D}_{3}$ from the plasma of the $\mathrm{DBP}^{-/-}$mice was investigated. Urine was collected from the $\mathrm{DBP}^{+/+}$and $\mathrm{DBP}^{-/-}$animals for 24 hours after intravenous injection of the tracer
$25(\mathrm{OH})\left[{ }^{3} \mathrm{H}\right] \mathrm{D}_{3}$. Threefold more isotope was excreted into the urine of the $\mathrm{DBP}^{-/}$group than the wild-type controls (Fig. $5 b$ ). Total urine $25(\mathrm{OH}) \mathrm{D}$ content was specifically quantified by radioimmunoassay (RIA) as well. A 2.4-fold greater clearance was observed over a 24hour period in the $\mathrm{DBP}^{-/-}$mice $\left(\mathrm{DBP}^{+/+}, 149 \mathrm{pg} / 24\right.$ hours; $\mathrm{DBP}^{-/-}, 361 \mathrm{pg} / 24$ hours). Aliquots of plasma harvested at each time point of the short time course (Fig. $5 a$ and inset) were extracted and fractionated by TLC. The percentage of total plasma tritium migrating at either the $25(\mathrm{OH}) \mathrm{D}$ position or at the more polar end of the chromatography media was plotted (Fig. $5 c$ ). Ninety-five percent of the injected $25(\mathrm{OH})\left[{ }^{3} \mathrm{H}\right] \mathrm{D}_{3}$ remained in the 25 -hydroxylated form, even at 40 minutes, in the wildtype animal, whereas only $46 \%$ remained in this form in the $\mathrm{DBP}^{-/-}$animals. In the $\mathrm{DBP}^{-/-}$mouse, $13 \%$ of the plasma tritium migrated as more polar metabolites at 40 minutes in contrast to $2 \%$ in the wild-type animal. These data suggested that in the absence of DBP, the injected $25(\mathrm{OH}) \mathrm{D}$ was being more rapidly metabolized and excreted in the urine in the absence of DBP.

The role of DBP in determining the kinetics and hepatic uptake of vitamin D has received less study. In vivo, it is known that some vitamin $\mathrm{D}$ is presented to the liver on low-density lipoprotein (LDL) and chylomicron remnants, and some redistributes to other plasma carriers, including DBP, albumin, and other lipoproteins (33). To determine the importance of DBP in vitamin $\mathrm{D}$ serum transport and metabolism, $\mathrm{DBP}^{+/+}$and $\mathrm{DBP}^{-/-}$mice were fed vitamin D-deficient diets for four weeks. Each mouse was then injected intravenously with $\left[{ }^{3} \mathrm{H}\right]$ vitamin $\mathrm{D}_{3}$ that 


\section{Figure 6}

Accelerated entry of serum $\left[{ }^{3} \mathrm{H}\right]$ vitamin $\mathrm{D}$ into the liver and its conversion to polar metabolites. $\left[{ }^{3} \mathrm{H}\right]$ vitamin $\mathrm{D}_{3}$ was preincubated with aliquots of $\mathrm{DBP}^{+/+}$or $\mathrm{DBP}^{-/-}$ serum and injected intravenously into mice in the respective groups. Plasma samples ( $\boldsymbol{a})$ and livers $(\boldsymbol{b})$ were harvested at the indicated times after injection, and tritium counts were obtained. Data were expressed as a percentage of total cpm injected normalized to total plasma volume $(P<0.05$ at 20 and 40 min; $a$ ) or per gram of liver $(b)$, and represent the mean \pm SEM from three independent experiments. (c) Aliquots of plasma from the 1-min time point in $a$ were extracted and subjected to TLC. The position of a $25(\mathrm{OH}) \mathrm{D}$ standard was localized by ultraviolet visualization, and the percentage of total chromatographed cpm migrating in the $25(\mathrm{OH}) \mathrm{D}$ region was plotted. $(\boldsymbol{d})$ The percentage of total chromatographed cpm migrating in the polar region was plotted. The data are the mean \pm SEM of two to three independent experiments. $a$

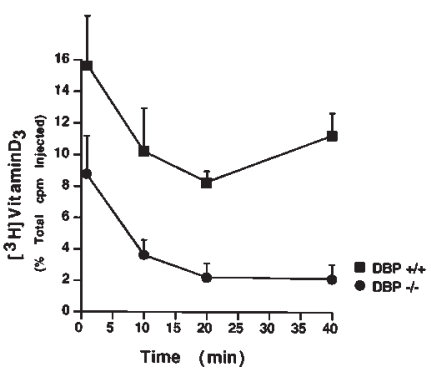

c

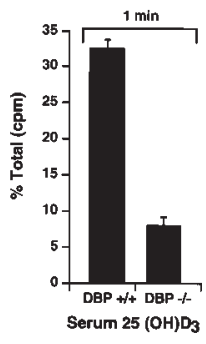

b

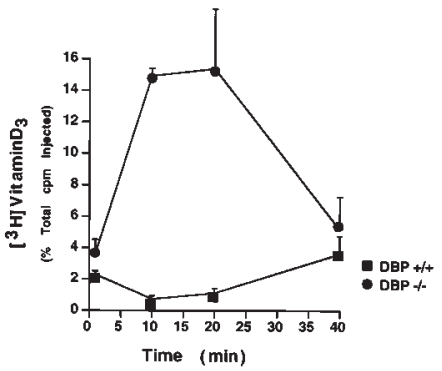

$d$

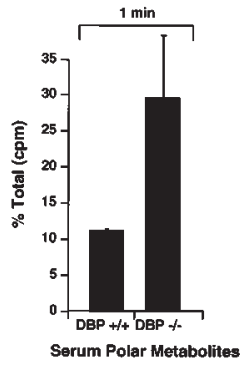

had been preincubated in homologous serum. These animals were sacrificed over a period of 40 minutes, plasma was collected, and livers were homogenized. The clearance of $\left[{ }^{3} \mathrm{H}\right]$ vitamin $\mathrm{D}_{3}$ from the $\mathrm{DBP}^{-/-}$plasma was substantially more rapid than from the $\mathrm{DBP}^{+/+}$plasma (Fig. $6 a)$. A reciprocal pattern of $\left[{ }^{3} \mathrm{H}\right]$ vitamin $\mathrm{D}_{3}$ uptake was seen in the livers. Between 10 and 20 minutes after injection, tritium counts were 14-15-fold higher in the livers of the $\mathrm{DBP}^{-/-}$animals than in the $\mathrm{DBP}^{+/+}$controls (Fig. $6 b$ ). By 40 minutes after injection, the level of tritium in the $\mathrm{DBP}^{-/-}$livers fell to a value indistinguishable from the $\mathrm{DBP}^{+/+}$controls. This pattern suggested that the accelerated transfer of $\left[{ }^{3} \mathrm{H}\right]$ vitamin $\mathrm{D}_{3}$ from the serum to the liver of the $\mathrm{DBP}^{-/-}$mice was followed by egress of isotope from the liver. This accelerated entry into the liver appeared to be an effect specific to this organ because there was less isotope detected in the kidney parenchyma of $\mathrm{DBP}^{-/-}$animals at all time points (not shown).

The accelerated rate of transfer of vitamin $\mathrm{D}_{3}$ from the serum to the liver in the $\mathrm{DBP}^{-/}$- mice might be paralleled by the hepatocyte-mediated 25-hydroxylation to $25(\mathrm{OH}) \mathrm{D}$ or conversion of the vitamin D to water-soluble inactive esters that could then be excreted (34). To determine which pathway was being used, aliquots of plasma from the one-minute time points of each $\left[{ }^{3} \mathrm{H}\right]$ vitamin $\mathrm{D}_{3}$ kinetic experiment were extracted and subjected to TLC. One minute after injection, a mean of $32 \%$ of the total plasma tritium migrated at the $25(\mathrm{OH})\left[{ }^{3} \mathrm{H}\right] \mathrm{D}$ position on thin-layer chromatographic analysis in the wild-type animals compared with $7.5 \%$ in the $\mathrm{DBP}^{-/-}$animals (Fig. $6 \mathrm{c}$ ). At the same time point, almost three times more polar metabolites were detected in $\mathrm{DBP}^{-/-}$mice than in $\mathrm{DBP}^{+/+}$mice $(29 \%$ and $11 \%$, respectively). Thus, the accelerated entry of vitamin $D$ into the liver in the absence of DBP appeared to result in the shunting of a substantial proportion of the substrate into an inactivating pathway or pathways. The relative contributions of liver and other tissues to this pathway cannot be determined from the present data.

The toxic response to high-level vitamin $D$ administration was decreased in the absence of $D B P$. The profile of serum clearance and hepatic modification of vitamin $D$ seen in the $\mathrm{DBP}^{-/-}$mouse suggested that DBP was necessary for efficient hepatic 25-hydroxylation and subsequent activation. This observation would suggest that the biologic activity of administered vitamin $\mathrm{D}$ would be significantly blunted in $\mathrm{DBP}^{-/-}$mice. This result would contradict the prediction from the free-hormone hypothesis that the lack of serum DBP in the $\mathrm{DBP}^{-/-}$mouse would accentuate the effects of a given dose of vitamin $\mathrm{D}$ due to absence of its putative buffering action (13). To differentiate between these two predictions, the effect of a sublethal dose (1000 IU/g body weight) of vitamin $\mathrm{D}_{3}$ was compared between wild-type and DBP-deficient mice. There were no significant differences in weight loss between the two groups over a one-week period of observation after delivery of vitamin D (data not shown). At day 7, the animals were sacrificed, serum was collected, and kidneys were harvested. The large dose of vitamin D resulted in the expected increase in serum calcium levels in the $\mathrm{DBP}^{+/+}$mice compared with control mice injected with vehicle only. Remarkably, the $\mathrm{DBP}^{-/-}$mice responded to the same dose of vitamin $\mathrm{D}$ with a significantly less pronounced increase in serum calcium (Fig. 7a); von Kossa staining of kidneys confirmed the greater effect of the vitamin $\mathrm{D}$ dose on serum calcium levels in the $\mathrm{DBP}^{+/+}$ mice by demonstrating correspondingly more significant accumulation of calcium deposits in the cortices of the $\mathrm{DBP}^{+/+}$kidneys (Fig. 7,b-e). Thus, the lack of serum DBP resulted in relative protection of the $\mathrm{DBP}^{-/-}$mice from the toxicity of high-dose vitamin D administration.

$1,25(\mathrm{OH})_{2} \mathrm{D}$-dependent gene induction is more rapid in the absence of DBP. $\mathrm{DBP}^{-/-}$mice were more susceptible to vitamin $D$ deficiency and were relatively resistant to vitamin D toxicity (Figs. 3 and 7). This observation could imply that the bioactivity of $1,25(\mathrm{OH})_{2} \mathrm{D}$ is in some way dependent on DBP. The importance of DBP to the delivery of biologically active $1,25(\mathrm{OH})_{2} \mathrm{D}$ to target tissues and the activation of gene expression was tested. Induction of calbindin- $\mathrm{D}_{9 \mathrm{~K}} \mathrm{mRNA}$ in the proximal small intestine is 
dependent on $1,25(\mathrm{OH})_{2} \mathrm{D}$. The steady-state levels of proximal intestinal calbindin- $\mathrm{D}_{9 \mathrm{~K}} \mathrm{mRNA}$ were determined in vitamin $\mathrm{D}$-deficient $\mathrm{DBP}^{+/+}$and $\mathrm{DBP}^{-/-}$mice 24 hours after intravenous injection of $1,25(\mathrm{OH})_{2} \mathrm{D}$. Before injection $(t=0)$, proximal intestinal levels of calbindin- $\mathrm{D}_{9 \mathrm{~K}}$ mRNA were identical (Fig. 8, $a$ and $b$ ). Immediately after injection of $1,25(\mathrm{OH})_{2} \mathrm{D}$, there was a transient depression in normalized calbindin- $\mathrm{D}_{9 \mathrm{~K}} \mathrm{mRNA}$ levels in both groups. This period was followed by a progressive increase to a peak value and a subsequent fall toward baseline values. The overall maximal levels at the peak of induction were similar in both groups, although the timing was different. In the $\mathrm{DBP}^{+/+}$animals, calbindin- $\mathrm{D}_{9 \mathrm{~K}}$ mRNA levels reached the maximum response 12 hours after $1,25(\mathrm{OH})_{2} \mathrm{D}$ injection. This kinetic response was in agreement with that previously reported in wild-type mice by others (35). In contrast, the calbindin- $\mathrm{D}_{9 \mathrm{~K}} \mathrm{mRNA}$ levels in the $\mathrm{DBP}^{-/-}$mice reached a similar maximal response at eight hours (Fig. 8, $a$ and $b$ ). These kinetic differences were statistically significant and reproducible over four experiments. Thus, DBP slowed the kinetics but not the overall level of calbindin- $\mathrm{D}_{9 \mathrm{~K}}$ gene expression in response to induction by $1,25(\mathrm{OH})_{2} \mathrm{D}$.

\section{Discussion}

A mouse model carrying a disrupted and functionally inactivated DBP locus was generated to investigate the role of DBP in vitamin D metabolism. The DBP allele was disrupted by targeted homologous recombination within exon 5 of the mouse DBP gene (Fig. 1). Assays on the sera of the mice homozygous for the disrupted DBP allele failed to detect immunoreactive DBP fragments or $25(\mathrm{OH})\left[{ }^{3} \mathrm{H}\right] \mathrm{D}_{3}$-binding peptides (Fig. $\left.2, b-d\right)$. The interruption of the endogenous mouse DBP locus was therefore felt to effectively eliminate expression of DBP and highaffinity serum binding of vitamin $\mathrm{D}$ and its metabolites.

Based on extensive population surveys, it was initially suspected that homozygosity for a DBP-null allele might result in embryonic or neonatal lethality (4). The generation of $\mathrm{DBP}^{-/-}$mice at the expected mendelian frequency from intercrosses between $\mathrm{DBP}^{+/-}$heterozygotes was therefore unexpected. These $\mathrm{DBP}^{-/-}$mice were normal in size and appearance, and intercrosses between $\mathrm{DBP}^{-/-}$ mice resulted in litters of normal size with no evidence of impairment of fertility in either males or females. It was concluded that a total absence of serum DBP was fully consistent with normal viability and reproduction.

The $\mathrm{DBP}^{-/-}$mice had significantly lower serum levels of $25(\mathrm{OH}) \mathrm{D}$ and $1,25(\mathrm{OH})_{2} \mathrm{D}$ compared with $\mathrm{DBP}^{+/+}$animals (Fig. 3). The free-hormone hypothesis states that the biological activity of a given hormone is related to its unbound ("free") rather than protein-bound concentration in the plasma (10). Thus, by binding to sterol or steroid hormones and trapping them in the vascular compartment, each binding protein creates a buffer or reservoir for its respective hormone (36). Normally, only $0.04 \%$ of $25(\mathrm{OH}) \mathrm{D}$ and $0.4 \%$ of $1,25(\mathrm{OH})_{2} \mathrm{D}$ are free, the remainder being bound to either DBP (85\%-88\%; high

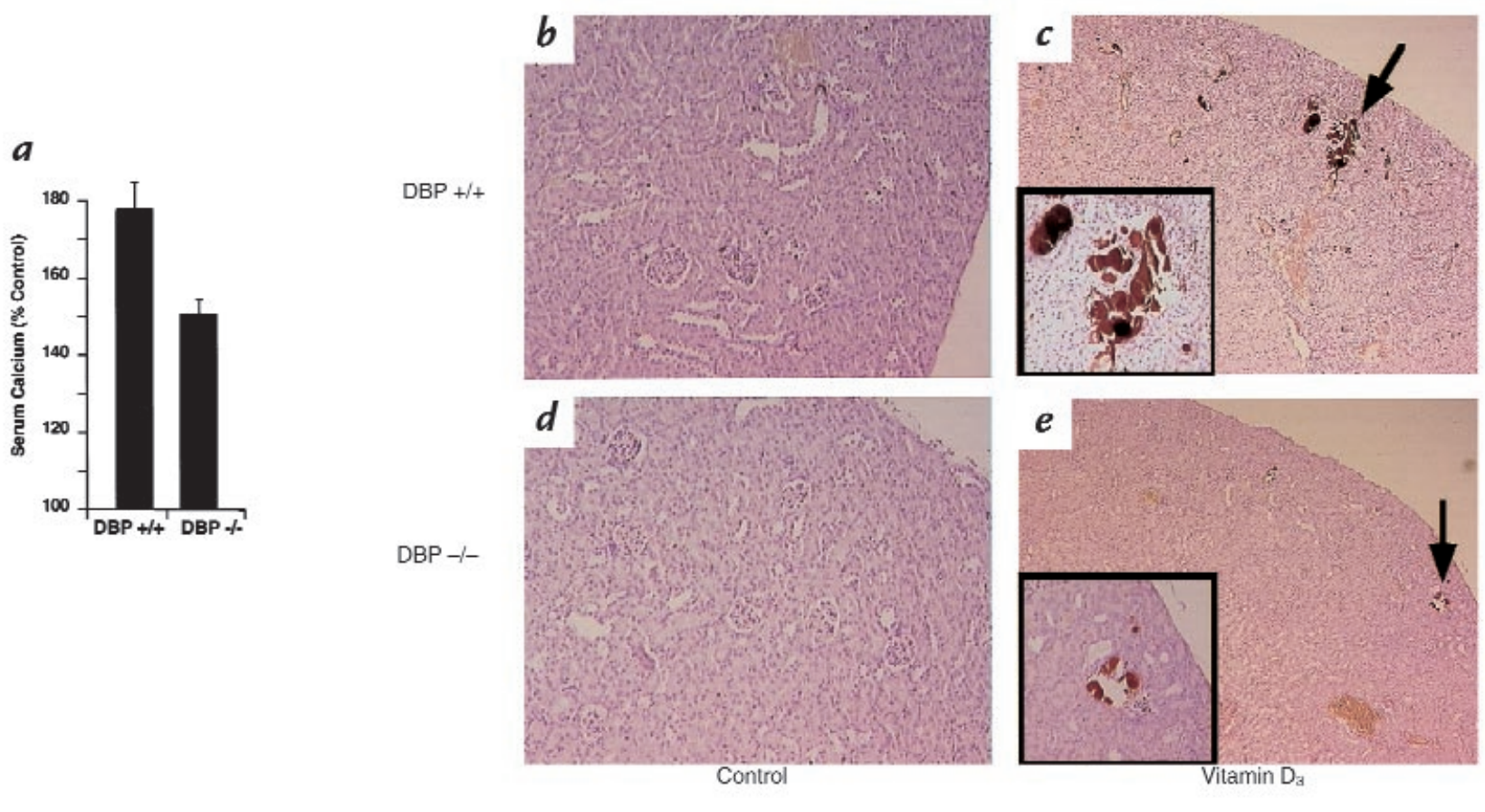

\section{Figure 7}

Relative resistance to vitamin $\mathrm{D}_{3}$ toxicity demonstrated by $\mathrm{DBP}^{-/-}$mice. $\mathrm{DBP}^{+/+}$and $\mathrm{DBP}^{-/-}$mice were injected with toxic doses of vitamin $\mathrm{D}$ or with vehicle alone. (a) Serum calcium levels were determined 7 days after injection, and results are expressed as a percentage of the serum calcium in the vehicle-injected control groups. The differences were significant in both comparisons: $\mathrm{DBP}^{+/+}$group $(P<0.001)$ and $\mathrm{DBP}-/-$ group $(P<0.01)$ compared with vehicle (not shown), and the calcium increase in the $\mathrm{DBP}^{+/+}$group compared with the $\mathrm{DBP}^{-/-}$group $(P<0.05$, shown). Seven days after injection, kidney sections were fixed and stained with von Kossa to detect calcium deposits. Representative kidney sections from DBP $+/+$ mice injected with vehicle $(\boldsymbol{b})$ or vitamin $\mathrm{D}(\boldsymbol{c})$, and $\mathrm{DBP}^{-/-}$mice injected with vehicle $(\boldsymbol{d})$ or vitamin $\mathrm{D}(\boldsymbol{e})$ are shown $(\times 10)$. The arrows $(c$ and $e)$ point to calcium deposits in the renal cortex, and these regions are shown in the insets $(\times 20)$. 


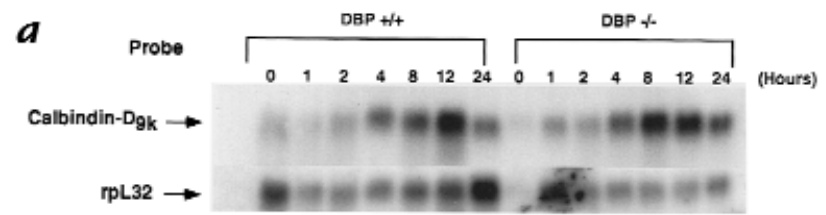

$\boldsymbol{b}$

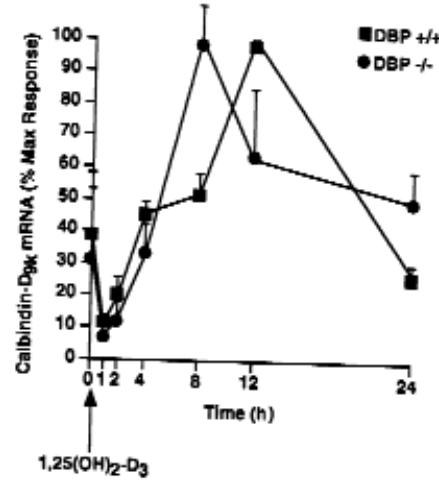

Figure 8

Accelerated activation of calbindin- $\mathrm{D}_{9 \mathrm{~K}}$ gene expression by $1,25(\mathrm{OH})_{2} \mathrm{D}$ in $\mathrm{DBP}^{-/-}$mice. (a) Vitamin D-deficient $\mathrm{DBP}^{+/+}$and $\mathrm{DBP}^{-/-}$mice were injected intravenously with $50 \mathrm{ng} 1,25(\mathrm{OH})_{2} \mathrm{D}_{3}$. Animals were sacrificed at the indicated times after injection, and RNA was isolated from the most proximal centimeter of small intestine. The RNA was analyzed by Northern blots hybridized with ${ }^{32} \mathrm{P}$-labeled calbindin- $\mathrm{D}_{9 \mathrm{~K}}$ and $\left[{ }^{32} \mathrm{P}\right] \mathrm{rpL} 32$ (loading control) probes. A representative autoradiogram is shown. (b) Relative band intensities were quantitated by Phosphorlmager and were normalized for RNA loading. The data presented are expressed as a percentage of the maximal calbindin- $\mathrm{D}_{9 \mathrm{~K}} \mathrm{mRNA}$ levels in response to $1,25(\mathrm{OH})_{2} \mathrm{D}_{3}$. The mean $\pm \mathrm{SEM}$ from four independent experiments is shown.

affinity) or albumin (12\%-15\%; low affinity) $(37,38)$. Only these free vitamin D sterols are considered to be biologically active (39). Therefore, the low total serum sterol levels observed in the $\mathrm{DBP}^{-/-}$mouse ( $20 \%-25 \%$ of wild-type levels) (Fig. 3, $a$ and $b$ ) might coexist in equilibrium with an adequate concentration of intracellular $1,25(\mathrm{OH})_{2} \mathrm{D}$ under steady-state conditions, even though the animal as a whole has lower circulating total concentrations of vitamin $\mathrm{D}$. The lack of biochemical indicators of functional vitamin D deficiency in the $\mathrm{DBP}^{-/-}$ mice was in agreement with this prediction.

To test whether the lack of DBP might precipitate functional vitamin $\mathrm{D}$ deficiency when dietary vitamin $\mathrm{D}$ was scarce, wild-type and $\mathrm{DBP}^{-/-}$mice were stressed by creating a mild state of dietary vitamin $\mathrm{D}$ depletion. Four weeks of the vitamin $\mathrm{D}$-deficient diet were sufficient to deplete serum $25(\mathrm{OH}) \mathrm{D}$ and $1,25(\mathrm{OH})_{2} \mathrm{D}$ levels in the wild-type mice. Although there were no changes in serum calcium levels, serum phosphate levels decreased, with a reciprocal increase in alkaline phosphatase levels in both groups. These values, however, did not become statistically significant until six weeks of vitamin D deficiency had been imposed (Table 1). The increase in alkaline phosphatase, possibly related to accelerated bone turnover in response to vitamin $\mathrm{D}$ deficiency, was more marked in the $\mathrm{DBP}^{-}-$- mice, and this group of mice selectively displayed a significant elevation in PTH. This selective appearance of secondary hyperparathyroidism in the $\mathrm{DBP}^{-/-}$mice was highly statistically significant (Fig. 3f). Because secondary hyperparathyroidism is a response to relative extracellular hypocalcemia, and perhaps a direct effect of depressed levels of free $1,25(\mathrm{OH})_{2} \mathrm{D}(40)$, it was concluded that a true functional $1,25(\mathrm{OH})_{2} \mathrm{D}$ deficiency state had developed in the $\mathrm{DBP}^{-/-}$- but not in the wild-type mice. Thus, DBP afforded wild-type mice a degree of protection against dietary-induced vitamin $\mathrm{D}$ deficiency.

The bone is a target of vitamin $\mathrm{D}$ action, and the elevated alkaline phosphatase values, along with the secondary hyperparathyroidism, suggested an increased rate of bone matrix turnover in the $\mathrm{DBP}^{-/-}$animals. Bone histomorphometry (41) was carried out to define the effects of the vitamin $\mathrm{D}$-deficient diet on the $\mathrm{DBP}^{-/-}$mice. The pathophysiology of vitamin D deficiency in this organ is initiated by increased osteolysis due to the secondary hyperparathyroidism. An increase in osteoid, the formative surface on which bone mineralization occurs, is invariably present in the osteomalacia associated with vitamin D deficiency (42). Thus, the earliest stage of vitamin $\mathrm{D}$ deficiency in the bone is marked by a mean increase in osteoid seam width (43). Furthermore, a positive correlation between osteoid thickness and osteoid surface is specific to osteomalacia secondary to vitamin $\mathrm{D}$ deficiency in distinction to defects seen in secondary hyperparathyroidism due to other causes (43). After mild dietary vitamin $\mathrm{D}$ deprivation, the $\mathrm{DBP}^{-/}$- mice showed just such an increased osteoid surface and osteoid thickness compared with $\mathrm{DBP}^{+/+}$mice (Fig. 4, $a$ and $b$ ). Defective mineralization of osteoid is the second invariant feature of hypovitaminosis D osteopathy (42). In $\mathrm{DBP}^{-/-}$ mice, the parameters of MS/BS, which indicates the percentage of cancellous bone surface containing the fluorochrome labels, and the MAR were significantly reduced compared with $\mathrm{DBP}^{+/+}$mice. These indices reflect the amount of newly mineralized osteoid matrix and suggested a mineralization defect in the $\mathrm{DBP}^{-/-}$mice. Overall, the histomorphometric data suggested that the low vitamin D sterol levels in the vitamin D-depleted $\mathrm{DBP}^{-/-}$ animals were associated with the metabolic bone disease of vitamin D deficiency, and these abnormalities were not manifest in comparably depleted $\mathrm{DBP}^{+/+}$mice. Therefore, bone disease, indicative of intracellular vitamin D deficiency, developed in the $\mathrm{DBP}^{-/-}$mice but not in the wildtype mice after mild dietary vitamin $\mathrm{D}$ deprivation.

The plasma clearance and fate of intravenously injected $25(\mathrm{OH})\left[{ }^{3} \mathrm{H}\right] \mathrm{D}_{3}$ were studied to determine whether the pathologic effects of the vitamin $\mathrm{D}$ deficiency seen in the $\mathrm{DBP}^{-/-}$mice were due to abnormal metabolism of the vitamin D sterols in the absence of DBP. The distribution of the isotope in vivo and the rates of conversion of vitamin $\mathrm{D}$ to $25(\mathrm{OH}) \mathrm{D}$ or to biologically inactive products were compared in the $\mathrm{DBP}^{-/-}$and $\mathrm{DBP}^{+/+}$mice. Avoidance of the more typical intraperitoneal injection route in favor of intravenous injection of labeled vitamin $\mathrm{D}$ and $25(\mathrm{OH}) \mathrm{D}$ was critical for these studies because it was unknown whether non-DBP serum carriers could retrieve peritoneal sterols into the bloodstream as efficiently in the $\mathrm{DBP}^{-/}$animal as $\mathrm{DBP}$ could in the $\mathrm{DBP}^{+/+}$ animals. Another important feature of the experimental design was the delivery of the sterols bound to homologous sera; the sterols should be distributed on the several plasma carrier proteins in a fashion natural for each genotype, eliminating the variable of organic solvents. 
The very rapid plasma clearance of $25(\mathrm{OH})\left[{ }^{3} \mathrm{H}\right] \mathrm{D}_{3}$ and its greater excretion in the urine in an unmodified form (Fig. $5 a$ ) in the absence of DBP suggested that binding of $25(\mathrm{OH}) \mathrm{D}$ by DBP slowed its direct filtration and excretion in urine (Fig. 5b). This model was supported by the results of the thin-layer chromatographic fractionation of plasma samples from 0 through 40 minutes after $25(\mathrm{OH})\left[{ }^{3} \mathrm{H}\right] \mathrm{D}_{3}$ injection. These samples demonstrated a stable maintenance of the lipid-soluble tritiated $25(\mathrm{OH}) \mathrm{D}$ in $\mathrm{DBP}^{+/+}$mice but a rapid fall in $\mathrm{DBP}^{-/-}$mice (Fig. 5c). In contrast, polar metabolites increased over 40 minutes in $\mathrm{DBP}^{-/-}$mice but fell in $\mathrm{DBP}^{+/+}$mice, suggesting that a more rapid and reciprocal conversion of $25(\mathrm{OH}) \mathrm{D}$ to biologically inactive polar products was occurring. Thus, the $\mathrm{DBP}^{-/-}$mice demonstrated poor conservation of $25(\mathrm{OH}) \mathrm{D}$ in serum due to accelerated urinary excretion as well as metabolic inactivation.

In the absence of DBP, $\left[{ }^{3} \mathrm{H}\right]$ vitamin $\mathrm{D}_{3}$ entered the liver at an accelerated rate and was cleared from the serum more efficiently than in the wild-type animals (Fig. 6). These results suggested that DBP prolonged the serum half-life of vitamin D and retarded its entry into the liver and its subsequent metabolism. In a single-pass liver-perfusion system, removal of dietary vitamin $\mathrm{D}$ was shown to be greatest when it was carried by LDL or chylomicron remnants and thus occurred via receptor-mediated uptake. In contrast, the uptake of vitamin D by hepatocytes was significantly slower when carried on DBP (44). In vivo, some vitamin $\mathrm{D}$ is presented to the liver on $\mathrm{LDL}$ and chylomicrons and some will be presented on other plasma carriers (DBP, albumin, other lipoproteins), and the overall rate of uptake in the normal animals likely reflects the net internalization of these several carriers (33). It has been previously shown that rapid delivery of vitamin $\mathrm{D}$ to the liver leads to the rapid conversion of the excess to inactive forms and water-soluble conjugates by esterification (34). In the experiments reported here, more tritiated serum sterol was in the form of $25(\mathrm{OH}) \mathrm{D}$ in the wild type and in the form of polar metabolites in the $\mathrm{DBP}^{-/-}$group at one minute after injection. Thus, the rapid entry of vitamin $\mathrm{D}$ and its selective shunting to an esterification-excretion pathway would be consistent with the predictions from prior metabolic studies and consistent with this finding. The abnormal levels and conversion of vitamin D to water-soluble side products in the $\mathrm{DBP}^{-/-}$mice thus reflected the role of DBP in modulating hepatic uptake of vitamin D and its subsequent 25 -hydroxylation and activation. The loss of these functions contributed to the sensitivity of the $\mathrm{DBP}^{-/-}$mice to vitamin $\mathrm{D}$ deprivation as well as to their relative resistance to vitamin $\mathrm{D}$ toxicity.

Vitamin D toxicity is manifested by hypercalcemia, bone resorption, and calcification of soft tissues. In the face of vitamin $\mathrm{D}$ toxicity, conversion of vitamin $\mathrm{D}$ to the active $1,25(\mathrm{OH})_{2} \mathrm{D}$ form is normally downregulated, and $25(\mathrm{OH}) \mathrm{D}$ or one of its metabolic products has been proposed to be responsible for the direct toxic effect $(45,46)$. An alternative hypothesis proposes that the toxicity may be secondary to competition from the high levels of $25(\mathrm{OH}) \mathrm{D}$ for DBP binding, with resultant elevations of free $1,25(\mathrm{OH})_{2} \mathrm{D}(47)$. The response of the $\mathrm{DBP}^{-/-}$mice to vitamin $\mathrm{D}$ toxicity would thus test the importance of the presumed buffering capacity of DBP in vitamin D metabolism. $\mathrm{DBP}^{-/-}$mice were less susceptible to hypercalcemia and the secondary soft-tissue calcification of vitamin D toxicity than the wild-type controls (Fig. 7). Based on the previous results, the relative resistance of $\mathrm{DBP}^{-/-}$mice to the full effects of vitamin $\mathrm{D}$ toxicity may reflect the net effect of the more rapid direct urinary excretion of $25(\mathrm{OH}) \mathrm{D}$ and the more rapid conversion to inactive polar metabolites (Fig. 5). The protective effect of a DBP-null state is also consistent with the previous demonstration that toxic levels of $25(\mathrm{OH}) \mathrm{D}$ exceeding the normal levels of DBP's binding capacity result in an increased fractional liver uptake and increased biliary excretion (48). Furthermore, in the absence of DBP, the competition model would not be active. Thus, the buffering capacity of DBP is deleterious in the face of an abnormally high vitamin D load.

$25(\mathrm{OH}) \mathrm{D}$ has been demonstrated to enter cells independent of a carrier-mediated transport mechanism in vitro (49). Because of this action and the absence of evidence for functional vitamin $\mathrm{D}$ deficiency in $\mathrm{DBP}^{-/-}$animals on normal diets, it can be predicted that a fraction of the serum 25(OH)D was taken up by the kidney for 1hydroxylation in $\mathrm{DBP}^{-/-}$mice. Because the serum levels of $25(\mathrm{OH}) \mathrm{D}$ in the $\mathrm{DBP}^{-/-}$mice were significantly low (Fig. 3), a continuous input of dietary vitamin $\mathrm{D}$ would be required to maintain normal $1,25(\mathrm{OH})_{2} \mathrm{D}$ action in target tissues. This hypothesis is supported by the experimental results, demonstrating a marked sensitivity of the $\mathrm{DBP}^{-/-}$mice to dietary deficiency of vitamin $\mathrm{D}$.

Whether sterol-binding proteins facilitate or hinder entry of the corresponding sterol into a target cell remains a critical question. It has been demonstrated that many steroid-binding proteins are associated with cell surface

\section{Table 1}

Serum calcium, phosphorous, and alkaline phosphatase in wild-type and $\mathrm{DBP}^{-/-}$mice on standard and vitamin D-deficient diets

\begin{tabular}{|c|c|c|c|c|}
\hline Genotype & $\begin{array}{c}\text { Diet } \\
\text { (weeks } \\
\text { vitamin } \\
\text { D-deficient) }\end{array}$ & $\begin{array}{c}\mathrm{Ca}^{2+} \\
(\mathrm{mg} / \mathrm{dl})\end{array}$ & $\begin{array}{c}P \\
(\mathrm{mg} / \mathrm{dl})\end{array}$ & $\begin{array}{c}\text { Alkaline } \\
\text { phosphatase } \\
(U / I)\end{array}$ \\
\hline $\mathrm{DBP}^{+/+}$ & 0 & $\begin{array}{c}8.0 \pm 0.3 \\
(9)\end{array}$ & $\begin{array}{c}11.4 \pm 1.0 \\
(9)\end{array}$ & $\begin{array}{c}74 \pm 28 \\
(9)\end{array}$ \\
\hline $\mathrm{DBP}^{-/-}$ & 0 & $\begin{array}{c}7.9 \pm 0.8 \\
(15)\end{array}$ & $\begin{array}{c}10.3 \pm 1.5 \\
(16)\end{array}$ & $\begin{array}{c}94 \pm 26 \\
(15)\end{array}$ \\
\hline $\mathrm{DBP}^{+/+}$ & 4 & $\begin{array}{c}8.3 \pm 0.6 \\
\text { (9) }\end{array}$ & $\begin{array}{c}8.0 \pm 1.0^{\mathrm{A}} \\
(8)\end{array}$ & $\begin{array}{c}90 \pm 31 \\
(15)\end{array}$ \\
\hline $\mathrm{DBP}^{-/-}$ & 4 & $\begin{array}{c}8.3 \pm 0.4 \\
(8)\end{array}$ & $\begin{array}{c}8.8 \pm 1.2^{\mathrm{B}} \\
(8)\end{array}$ & $\begin{array}{c}126 \pm 46 \\
(7)\end{array}$ \\
\hline $\mathrm{DBP}^{+/+}$ & 6 & $\begin{array}{c}7.5 \pm 1.0 \\
(14)\end{array}$ & N.D. & $\begin{array}{c}119 \pm 42^{c} \\
(15)\end{array}$ \\
\hline $\mathrm{DBP}^{-/-}$ & 6 & $\begin{array}{c}7.8 \pm 0.8 \\
(13)\end{array}$ & N.D. & $\begin{array}{c}131 \pm 41 c \\
(14)\end{array}$ \\
\hline
\end{tabular}

For comparisons between vitamin D-deficient and standard diet groups of the same genorype: ${ }^{A} P<0.0001,{ }^{B} P<0.001,{ }^{C} P<0.01$. 
receptors and can be internalized $(11,12,50)$. The same has been shown for albumin, a member of the DBP gene family that shares significant amino acid and secondary structural similarities with DBP but that is not a highaffinity steroid/sterol binding protein (4). A variety of cell types have been shown to have DBP on their surfaces through immunohistochemical and immunofluorescent analyses (51-55), suggesting that DBP might mediate entry of vitamin D sterols into the cell. However, in its role as a circulating reservoir for the vitamin D sterols, DBP might alternatively slow the entry of $1,25(\mathrm{OH})_{2} \mathrm{D}$ into its target cells by regulating the amount of free sterol available. These possibilities were tested by comparing the kinetics of $1,25(\mathrm{OH})_{2} \mathrm{D}$ induction of calbindin- $\mathrm{D}_{9 \mathrm{~K}}$ gene expression in vivo. Induction of calbindin- $\mathrm{D}_{9 \mathrm{~K}}$ gene expression has served as a sensitive indicator of the biological response of target tissues to $1,25(\mathrm{OH})_{2} \mathrm{D}$ action. $(56,57)$. In the mouse, administration of $1,25(\mathrm{OH})_{2} \mathrm{D}$ to vitamin D-deficient animals has been shown to induce a fourfold increase in transcription of the calbindin- $\mathrm{D}_{9 \mathrm{~K}}$ gene in proximal mouse intestine and a 20 -fold induction in the kidney (35). To determine whether the absence of DBP modified the kinetics of calbindin- $\mathrm{D}_{9 \mathrm{~K}}$ gene induction by altering the rate at which the hormone entered the target tissue, $1,25(\mathrm{OH})_{2} \mathrm{D}$ was injected intravenously and the levels of calbindin- $\mathrm{D}_{9 \mathrm{~K}} \mathrm{mRNA}$ were monitored in the proximal intestine. The experiment revealed two observations relevant to DBP's role in gene activation. First, the magnitudes of $1,25(\mathrm{OH})_{2} \mathrm{D}$ induction of calbindin- $\mathrm{D}_{9 \mathrm{~K}}$ in vitamin $\mathrm{D}$-depleted $\mathrm{DBP}^{+/+}$and $\mathrm{DBP}^{-/-}$mice were found to be nearly identical (Fig. 8a). Thus, in the absence of DBP, a $1,25(\mathrm{OH})_{2} \mathrm{D}$-sensitive gene could still mount a full response to $1,25(\mathrm{OH})_{2} \mathrm{D}$ stimulation. The second result was that the kinetic profiles of the response differed (Fig. $8 b$ ). The maximum response in $\mathrm{DBP}^{+/+}$intestine occurred 12 hours after injection, as previously reported (35), whereas the maximal response in $\mathrm{DBP}^{-/-}$proximal intestine occurred at eight hours. This more rapid induction of gene activation could be explained by more rapid entry of the sterol into the target cells of the $\mathrm{DBP}^{-/}$mice. Thus, the accelerated intracellular response to $1,25(\mathrm{OH})_{2} \mathrm{D}$ in the intestinal epithelial cells of the $\mathrm{DBP}^{-/-}$mouse paralleled the more rapid entry of $\left[{ }^{3} \mathrm{H}\right]$ vitamin D into liver (Fig. $6 b$ ).

DBP's primary role appeared to be the sequestration of vitamin D sterols in the serum, prolonging their serum half-lives and providing a circulating store of $25(\mathrm{OH}) \mathrm{D}$ to meet transient periods of vitamin $\mathrm{D}$ deficiency. In so doing, DBP helped to prevent the development of severe vitamin $\mathrm{D}$ deficiency that leads to bone mineralization defects and the ultimate development of osteomalacia or rickets. As an adjunct to its role in conservation and optimization of vitamin D, DBP appeared to minimize direct urinary losses of the sterols and to slow their entry into metabolic breakdown pathways. One corollary of this phenomenon is that $\mathrm{DBP}^{-/-}$mice, totally lacking DBP, manifested a need for continual intake of vitamin $\mathrm{D}$ to avoid the deficiency syndrome and also a reciprocal resistance to vitamin $\mathrm{D}$ toxicity in the face of increased sterol load. A testable clinical prediction from these findings is that patients with nephrotic syndrome and decreased serum DBP levels might be more vulnerable to osteomalacia or rickets. It would appear that evolution, in estab- lishing high levels of DBP, has favored the need for conservation and optimal utilization of dietary vitamin D over the more unlikely danger of dietary-induced toxicity.

\section{Acknowledgments}

The authors thank Michael Holick for $\left[{ }^{3} \mathrm{H}\right]$ vitamin D, Leonard Deftos for the measurement of serum PTH levels, David B.P. Goodman for use of the Kodak Ektachem analyzer, Gideon Rodan for his support and review of the manuscript, Glenn Gerhard for early contribution to the project, and members of the Cooke and Liebhaber Laboratories for their critical input. Jean Richa and the Transgenic and Chimeric Mouse Core of the University of Pennsylvania provided invaluable assistance with the blastocyst microinjections. Jessie Harper's assistance with computer imaging and Pei Fu He's management of the mouse colony are gratefully acknowledged. This work was supported by National Institutes of Health grant R01 GM32035 (to N.E. Cooke).

1. Cooke, N.E., and Haddad, J.G. 1997. Vitamin D binding protein. In Vitamin D. D. Feldman, F.H. Glorieux, and J.W. Pike, editors. Academic Press. San Diego, CA. 87-100.

2. Cooke, N.E. 1986. Rat vitamin D binding protein: determination of the full-length primary structure from cloned cDNA. J. Biol. Chem. 261:3441-3450.

3. Haddad, J.G., and Walgate, J. 1976. 25-Hydroxyvitamin D transport in human plasma: isolation and partial characterization of calciferol-binding protein. J. Biol. Chem. 251:4803-4809.

4. Cooke, N.E., and Haddad, J.G. 1989. Vitamin D binding protein (Gcglobulin). Endocrinol. Rev. 10:294-307.

5. McLeod, J., Kowalski, M.A., and Haddad, J.G. 1989. Interactions among serum vitamin D binding protein, monomeric actin, profilin, and profilactin. J. Biol. Chem. 264:1260-1267.

6. Haddad, J.G., et al. 1992. Identification of the sterol- and actin-binding domains of plasma vitamin D binding protein (Gc-globulin). Biochemistry. 31:7174-7181.

7. Lee, W.M., and Galbraith, R.M. 1992. The extracellular actin-scavenger system and actin toxicity. N. Engl. J. Med. 326:1335-1341.

8. Yamamoto, N., Homma, S., Haddad, J.G., and Kowalski, M.A. 1991. Vitamin $\mathrm{D}_{3}$ binding protein required for in vitro activation of macrophages after dodecylglycerol treatment of mouse peritoneal cells. Immunology. 74:420-424.

9. Kew, R.R., Fisher, J.A., and Webster, R.O. 1995. Co-chemotactic effect of Gc-globulin (DBP) for C5a: transient conversion into an active cochemotaxin by neutrophils. I. Immunol. 155:5369-5374.

10. Mendel, C.M. 1989. The free hormone hypothesis: a physiologicallybased mathematical model. Endocr. Rev. 10: 232-274.

11. Nakhla, A.M., Khan, M.S., Romas, N.A., and Rosner, W. 1994. Estradiol causes the rapid accumulation of cAMP in human prostate. Proc. Natl. Acad. Sci. USA. 91:5402-5405.

12. Joseph, D.R. 1994. Structure, function, and regulation of androgenbinding protein/sex hormone-binding globulin. Vitam. Horm. 49:197-280.

13. Thys-Jacob, S., Chan, F.K.W., Koberle, L.M.C., and Bilezikian, J.P. 1997. Hypercalcemia due to vitamin D toxicity. In Vitamin D. D. Feldman, F.H. Glorieux, and J.W. Pike, editors. Academic Press. San Diego, CA. 889-897.

14. Cleve, H., and Constans, J. 1988. The mutants of the vitamin-D binding protein: more than 120 variants of the Gc/DBP system. Vox Sang. 54:215-225.

15. Meyuhas, O., and Perry, R.P. 1980. Construction and identification of cDNA clones for mouse ribosomal protein gene expression. Gene. 10:113-129.

16. Ray, K., Wang, X., Zhao, M., and Cooke, N.E. 1991. Structure of the rat vitamin D binding protein (Gc-globulin) gene: structural analysis, functional and evolutionary correlations. J. Biol. Chem. 266:6221-6229.

17. McCarrick, J.W., III, Parnes, J.R., Seong, R.H., Solter, D., and Knowles, B.B. 1993. Positive-negative selection gene targeting with the diphtheria toxin A-chain gene in mouse embryonic stem cells. Transgenic Res. 2:183-190.

18. Robertson, E.J. 1987. Embryo-derived stem cell lines. In Teratocarcinomas and embryonic stem cells: a practical approach. E.J. Roberston, editor. IRL Press. Oxford, United Kingdom. 71-112.

19. Feuerstein, R., Wang, X., Song, D., Cooke, N.E., and Liebhaber, S.A. 1994. The LIM/double zinc-finger motif functions as a protein dimerization domain. Proc. Natl. Acad. Sci. USA. 91:10655-10659.

20. Haddad, J.G., and Chyu, K.J. 1971. Competitive protein-binding radioassay for 25-hydroxycholecalciferol. J. Clin. Endocrinol. Metab. 33:992-995.

21. Rosenthal, H.E. 1967. A graphic method for the determination and pres- 
entation of binding parameters in a complex system. Anal. Biochem. 20:525-532.

22. Monstein, H., Nylander, A., and Chen, D. 1995. RNA extraction from gastrointestinal tract and pancreas by a modified Chomczynski and Sacchi method. Biotechniques. 19:340-345.

23. Onishi, T., Bone, H.G., III, Catherwood, B.D., and Deftos, L.J. 1983. A rat model for hormone and mineral changes in chronic renal failure. Proc. Soc. Exp. Biol. Med. 174:2193-2197.

24. Hollis, B.W., Kamerud, J.Q., Selvaag, S.R., Lorenz, J.D., and Napoli, J.L. 1993. Determination of vitamin D status by radioimmunoassay with a ${ }^{125}$ I-labeled tracer. Clin. Chem. 39:529-533.

25. Hollis, B.W., Kamerud, J.Q., Kurkowski, A., Beaulieu, J., and Napoli, J.L. 1996. Quantification of circulating 1,25-dihydroxyvitamin D by radioimmunoassay with a ${ }^{125}$ I-labeled tracer. Clin. Chem. 42: 586-592.

26. Recker, R.R. 1983. Bone histomorphometry: techniques and interpretation. CRC Press. Boca Raton, FL. 13-36.

27. Yamamoto, M., et al. 1998. The integrin ligand echistatin prevents bone loss in ovariectomized mice and rats. Endocrinology. 139:1411-1419.

28. Parfitt, A.M., et al. 1987. Bone histomorphometric standardization of nomenclature, symbols, and units. J. Bone Miner. Res. 2:595-599.

29. Horst, R.L., Shepard, R.M., Jorgensen, N.A., and DeLuca, H.F. 1979. The determination of the vitamin $\mathrm{D}$ metabolites on a single plasma sample: changes during parturition in dairy cows. Arch. Biochem. Biophys. 192:512-523

30. Kaplan, H., Brewer, N., and Blair, H. 1983. Physiology. In The mouse in biomedical research III: normative biology, immunology, and husbandry. H. Foster, D. Small, and J. Fox, editors. Academic Press. New York, NY. 251.

31. Cook, M. 1983. Anatomy. In The mouse in biomedical research III: normative biology, immunology, and husbandry. H. Foster, D. Small, and J. Fox, editors. Academic Press. New York, NY. 115.

32. Tang, W.X., Bazaraa, H.M., Magiera, H., Cooke, N.E., and Haddad, J.G. 1996. Electrophoretic mobility shift assay identifies vitamin D binding protein (Gc-globulin) in human, rat, and mouse sera. Anal. Biochem 237:245-251.

33. Haddad, J.G. 1987. Traffic, binding and cellular access of vitamin D sterols. In Bone and mineral research. Vol. 5. W.A. Peck, editor. Elsevier Sci ence Publishers. Amsterdam, the Netherlands. 291-305.

34. Fraser, D.R. 1983. The physiological economy of vitamin D. Lancet. 1:969-972.

35. Li, H., and Christakos, S. 1991. Differential regulation by 1,25 dihydroxyvitamin $\mathrm{D}_{3}$ of calbindin- $\mathrm{D}_{9 \mathrm{~K}}$ and calbindin- $\mathrm{D}_{28 \mathrm{~K}}$ gene expression in mouse kidney. Endocrinology. 128:2844-2852.

36. Rosner, W. 1990. The functions of corticosteroid-binding globulin and sex hormone-binding globulin: recent advances. Endocrinol. Rev. 11:80-91.

37. Bikle, D.D., Siiteri, P.K., Ryzen, E., and Haddad, J.G. 1985. Serum protein binding of 1,25-dihydroxyvitamin $\mathrm{D}$ : a re-evaluation by direct measurement of free metabolite. J. Clin. Endocrinol. Metab. 61:969-975.

38. Bikle, D.D., et al. 1986. Assessment of the free fraction of 25 -hydroxyvitamin $\mathrm{D}$ in serum and its regulation by albumin and the vitamin $\mathrm{D}$ binding protein. J. Clin. Endocrinol. Metab. 63:954-959.

39. Bikle, D.D., and Gee, E. 1989. Free and not total 1,25-dihydroxyvitamin $\mathrm{D}$ regulates 25 -hydroxyvitamin $\mathrm{D}$ metabolism by keratinocytes. Endocrinology. 124:649-654.
40. Okazaki, I., Igarashi, T., and Kronenberg, H.M. 1988. 5'-flanking region of the parathyroid hormone gene mediates negative regulation by 1,25(OH $)_{2} \mathrm{D}_{3}$. J. Biol. Chem. 263:2203-2208.

41. Parffit, A.M. 1990. Osteomalacia and related disorders. In Metabolic bone disease and clinically-related disorders. 2 nd ed. L.V. Avioli and S.M. Krane, editors. W.B. Saunders. Philadelphia, PA. 329-396.

42. Teitelbaum, S.L. 1980. Pathological manifestations of osteomalacia and rickets. Clin. Endocrinol. Metab. 9:43-62.

43. Rao, D.S., Villaneuva, A., and Matthews, M. 1983. Histologic evaluation of vitamin $\mathrm{D}$ depletion in patients with intestinal malabsorption or dietary deficiency. In Clinical disorders of bone and mineral metabolism. B. Frame and J.T. Potts, Jr., editors. Excerpta Medica. Amsterdam, the Netherlands. 224-226.

44. Haddad, J.G., Jennings, A.S., and Aw, T.C. 1988. Vitamin D uptake and metabolism by perfused rat liver: influences of carrier proteins. Endocrinology. 123:498-504.

45. Hughes, M.R., Baylink, D.J, Jones, R.G., and Haussler, M.R. 1976. Radioligand receptor assay for 25-hydroxyvitamin $\mathrm{D}_{2} / \mathrm{D}_{3}$ and $1 \alpha, 25$-dihydroxyvitamin $\mathrm{D}_{2} / \mathrm{D}_{3}$. J. Clin. Invest. 58:61-70.

46. Shepard, R.M., and DeLuca, H. 1980. Plasma concentrations of vitamin $\mathrm{D}_{3}$ and its metabolites in the rat as influenced by vitamin $\mathrm{D}_{3}$ or 25hydroxyvitamin $\mathrm{D}_{3}$ intakes. Arch. Biochem. Biophys. 202:43-53.

47. Pettifor, J.M., et al. 1995. Serum levels of free 1,25-dihydroxyvitamin D in vitamin D toxicity. Ann. Intern. Med. 122:511-513.

48. Gascon-Barre, M. 1982. Biliary excretion of $\left[{ }^{3} \mathrm{H}\right]$-25-hydroxyvitamin $\mathrm{D}_{3}$ in the vitamin D-depleted rat. Am. J. Physiol. 242:G522-G532.

49. Haddad, J.G., Fraser, D.R., and Lawson, D.E.M. 1981. Vitamin D plasma binding protein: turnover and fate in the rabbit. J. Clin. Invest. 67:1550-1560.

50. Hyrb, D.J., Khan, M.S., Romas, N.A., and Rosner, W. 1990. The control of the interaction of sex hormone-binding globulin with its receptor by steroid hormones. J. Biol. Chem. 265:6048-6054.

51. Petrini, M., Emerson, D.L., and Galbraith, R.M. 1983. Linkage between surface immunoglobulin and cytoskeleton of B-lymphocytes may involve Gc protein. Nature. 306:73-74

52. Nestler, J.E., McLeod, J.F., Kowalski, M.A., Strauss, J.F., III, and Haddad, J.G. 1985. Detection of vitamin D-binding protein on the surface of cytotrophoblasts isolated from human placenta. Endocrinology. 117:243-247.

53. Danan, J.L., et al. 1985. Presence of immunoreactive vitamin D-binding protein in rat yolk cell endodermal cells. Endocrinology. 117:243-247.

54. Guoth, M., et al. 1990. Cell-surface vitamin D-binding protein (Gc globulin) is acquired from plasma. Endocrinology. 127:2313-2321.

55. Esteban, C., et al. 1992. Receptor-mediated uptake and processing of vitamin D-binding protein in human B-lymphoid cells. J. Biol. Chem. 267:10177-10183

56. Christakos, S., Gabrielides, C., and Rhoten, W.B. 1989. Vitamin Ddependent calcium binding proteins: chemistry, distribution, functional considerations, and molecular biology. Endocr. Rev. 10:3-26.

57. Dupret, J.M., Brun, P., and Thomasset, M. 1986. In vivo effects of transcriptional and translational inhibitors on duodenal vitamin D-dependent calcium binding protein messenger ribonucleic acid stimulation by 1,25-dihydroxycholecalciferol. Endocrinology. 119:2476-2483. 